\title{
Genome-wide mRNA profiling identifies X-box-binding protein 1 (XBP1) as an IRE1 and PUMA repressor
}

\author{
Magdalena Gebert ${ }^{1} \cdot$ Aleksandra Sobolewska $^{1} \cdot$ Sylwia Bartoszewska ${ }^{2} \cdot$ Aleksandra Cabaj $^{3} \cdot$ David K. Crossman $^{4}$. \\ Jarosław Króliczewski ${ }^{1}$ Piotr Madanecki ${ }^{1} \cdot$ Michał Dąbrowski ${ }^{3} \cdot$ James F. Collawn ${ }^{5} \cdot$ Rafal Bartoszewski $^{1}$ (1)
}

Received: 14 May 2021 / Revised: 17 September 2021 / Accepted: 28 September 2021 / Published online: 12 October 2021

(c) The Author(s) 2021

\begin{abstract}
Accumulation of misfolded proteins in ER activates the unfolded protein response (UPR), a multifunctional signaling pathway that is important for cell survival. The UPR is regulated by three ER transmembrane sensors, one of which is inositolrequiring protein 1 (IRE1). IRE1 activates a transcription factor, X-box-binding protein 1 (XBP1), by removing a 26-base intron from XBP1 mRNA that generates spliced XBP1 mRNA (XBP1s). To search for XBP1 transcriptional targets, we utilized an $X B P 1 s$-inducible human cell line to limit XBP1 expression in a controlled manner. We also verified the identified XBP1-dependent genes with specific silencing of this transcription factor during pharmacological ER stress induction with both an N-linked glycosylation inhibitor (tunicamycin) and a non-competitive inhibitor of the sarco/endoplasmic reticulum $\mathrm{Ca}^{2+}$ ATPase (SERCA) (thapsigargin). We then compared those results to the XBP1s-induced cell line without pharmacological ER stress induction. Using next-generation sequencing followed by bioinformatic analysis of XBP1-binding motifs, we defined an XBP1 regulatory network and identified XBP1 as a repressor of PUMA (a proapoptotic gene) and IRE1 mRNA expression during the UPR. Our results indicate impairing IRE1 activity during ER stress conditions accelerates cell death in ER-stressed cells, whereas elevating XBP1 expression during ER stress using an inducible cell line correlated with a clear prosurvival effect and reduced PUMA protein expression. Although further studies will be required to test the underlying molecular mechanisms involved in the relationship between these genes with XBP1, these studies identify a novel repressive role of XBP1 during the UPR.
\end{abstract}

Keywords XBP1s $\cdot \mathrm{UPR} \cdot \mathrm{ER}$ stress $\cdot B B C 3 \cdot \mathrm{XBP} 1 \mathrm{u} \cdot E R N 1$

\begin{tabular}{|c|c|c|}
\hline \multicolumn{2}{|c|}{ Abbreviations } & ATF3 \\
\hline \multirow{2}{*}{\multicolumn{2}{|c|}{$\begin{array}{ll}A C L Y & \text { ATP citrate } \\
\text { ANK2 } & \text { Ankyrin } 2\end{array}$}} & ATF6 \\
\hline & & $B B C 3$ \\
\hline$\triangle$ & Rafal Bartoszewski & BSA \\
\hline & rafalbar@gumed.edu.pl & $C A L R$ \\
\hline 1 & Department of Biology and Pharmaceutical Botany, Medical & CDK6 \\
\hline & University of Gdansk, Hallera 107, 80-416 Gdansk, Poland & $C D K N 1 A$ \\
\hline 2 & $\begin{array}{l}\text { Department of Inorganic Chemistry, Medical University } \\
\text { of Gdansk, Gdansk, Poland }\end{array}$ & $C E B P B$ \\
\hline 3 & $\begin{array}{l}\text { Laboratory of Bioinformatics, Nencki Institute } \\
\text { of Experimental Biology of the Polish Academy of Sciences, } \\
\text { Warsaw, Poland }\end{array}$ & CHACl \\
\hline 4 & $\begin{array}{l}\text { Department of Genetics, Heflin Center for Genomic Science, } \\
\text { University of Alabama at Birmingham, Birmingham, }\end{array}$ & CHOP \\
\hline & AL 35233, USA & CLIP2 \\
\hline 5 & $\begin{array}{l}\text { Department of Cell, Developmental and Integrative Biology, } \\
\text { University of Alabama at Birmingham, Birmingham, } \\
\text { AL } 35233 \text {, USA }\end{array}$ & CTRL \\
\hline
\end{tabular}

Activating transcription factor 3

Activating transcription factor 6

BCL2-Binding component 3

Binding immunoglobulin protein (glu-

cose-regulated protein 78, a.k.a. HSPA5)

Bovine serum albumin

Calreticulin

Cyclin-dependent kinase 6

Cyclin-dependent kinase inhibitor 1A

(a.k.a p21)

CCAAT-enhancer-binding protein beta

(a.k.a $C / E B P$ )

ChaC glutathione-specific gamma-glutamylcyclotransferase 1

CCAAT-enhancer-binding protein

homologous protein (a.k.a DDIT3)

Cytoplasmic linker 2

Control 


\begin{tabular}{|c|c|c|c|}
\hline DDIT3 & $\begin{array}{l}\text { DNA damage-inducible transcript } 3 \\
\text { (a.k.a CHOP) }\end{array}$ & MIST1 & $\begin{array}{l}\text { Basic helix-loop-helix family member } \\
\text { A15 }\end{array}$ \\
\hline DHCR24 & 24-Dehydrocholesterol reductase & NFKB2 & Nuclear factor kappa B subunit 2 \\
\hline DMSO & Dimethyl sulfoxide & NGS & Next-generation sequencing \\
\hline DNAJA1 & $\begin{array}{l}\text { DnaJ heat shock protein family (Hsp40) } \\
\text { member A1 }\end{array}$ & $\begin{array}{l}\text { PBS } \\
\text { PERK }\end{array}$ & $\begin{array}{l}\text { Phosphate-buffered saline } \\
\text { Protein kinase RNA-like ER kinase }\end{array}$ \\
\hline$D N A J B 2$ & $\begin{array}{l}\text { DnaJ heat shock protein family (Hsp40) } \\
\text { member B2 }\end{array}$ & PUMA & $\begin{array}{l}\text { BCL2-binding component } 3 \text { (a.k.a. } \\
\text { BBC3) }\end{array}$ \\
\hline DNAJB9 & $\begin{array}{l}\text { DnaJ heat shock protein family (Hsp40) } \\
\text { member B9 (a.k.a ERdj4) }\end{array}$ & $\begin{array}{l}\text { qPCR } \\
\text { qRT-PCR }\end{array}$ & $\begin{array}{l}\text { Quantitative polymerase chain reaction } \\
\text { Quantitative real-time PCR }\end{array}$ \\
\hline DNAJC3 & $\begin{array}{l}\text { DnaJ heat shock protein family (Hsp40) } \\
\text { member C3 }\end{array}$ & $\begin{array}{l}\text { RLU } \\
\text { RCAN1 }\end{array}$ & $\begin{array}{l}\text { Relative light units } \\
\text { Regulator of calcineurin } 1\end{array}$ \\
\hline$D S P$ & Desmoplakin & $R P L P O$ & Neutral ribosomal phosphoprotein P0 \\
\hline DUSP6 & Dual-specificity phosphatase 6 & RTCA & Real-time cell analysis \\
\hline ECL & Enhanced chemiluminescence & SD & Standard deviations \\
\hline EDEM1 & $\begin{array}{l}\text { ER degradation-enhancing alpha-man- } \\
\text { nosidase-like protein } 1\end{array}$ & $\begin{array}{l}\text { SEC23B } \\
\text { SERCA }\end{array}$ & $\begin{array}{l}\text { Coat complex II component } \\
\text { Sarco/endoplasmic reticulum }\end{array}$ \\
\hline EGRl & Early growth response 1 & & $\mathrm{Ca} 2+$ ATPase \\
\hline $\mathrm{eIF} 2 \alpha$ & Eukaryotic translation initiation factor $2 \mathrm{a}$ & siRNA & Small interfering RNA \\
\hline ER & Endoplasmic reticulum & SNAII & Snail family transcriptional repressor 1 \\
\hline ERAD & $\begin{array}{l}\text { Endoplasmic reticulum-associated } \\
\text { degradation }\end{array}$ & $\begin{array}{l}\mathrm{Tg} \\
\mathrm{Tm}\end{array}$ & $\begin{array}{l}\text { Thapsigargin } \\
\text { Tunicamycin }\end{array}$ \\
\hline ERLEC1 & ER lectin 1 & UPR & Unfolded protein response \\
\hline ERN1 & $\begin{array}{l}\text { Endoplasmic reticulum to nucleus signal- } \\
\text { ing } 1 \text { (a.k.a. IRE1) }\end{array}$ & $\begin{array}{l}\text { WARS } \\
X B P 1\end{array}$ & $\begin{array}{l}\text { Tryptophanyl-tRNA synthetase } \\
\text { X-box-binding protein } 1\end{array}$ \\
\hline FOXJ2 & Forkhead box $\mathrm{J} 2$ & $X B P 1 s$ & Spliced X-box-binding protein 1 \\
\hline$G A D D 34$ & $\begin{array}{l}\text { Growth arrest and DNA damage-induci- } \\
\text { ble protein (a.k.a } P P P 1 R 15 A)\end{array}$ & $\begin{array}{l}X B P 1 u \\
\text { ZNF432 }\end{array}$ & $\begin{array}{l}\text { Unspliced form of XBP1 } \\
\text { Zinc finger protein } 432\end{array}$ \\
\hline
\end{tabular}

$G A D D 45 A \quad$ Growth arrest and DNA damage-inducible alpha

GADD45B Growth arrest and DNA damage-inducible beta

GAPDH Glyceraldehyde 3-phosphate dehydrogenase

GEO Gene expression omnibus

HEK-293 cells Human embryonic kidney cells

HeLa Human cervix adenocarcinoma cells

HSPA1B

Heat shock protein family A (Hsp70) member $1 \mathrm{~B}$

HSPA5 Heat shock protein family A (Hsp70) member 5, (a.k.a. BIP)

HSPA6 Heat shock protein family (Hsp70) member 6

HSPA8 Heat shock protein family A (Hsp70) member 8

HUVECs Human primary endothelial cells

ICAM1 Intercellular adhesion molecule 1

ILIA Interleukin $1 \alpha$

IL6 Interleukin 6

IRE1 Inositol-requiring protein 1

MAP3K7 Mitogen-Activated Protein Kinase Kinase Kinase 7

MCF-7 Human breast cancer cell line

\section{Introduction}

Endoplasmic reticulum (ER) stress can disrupt the folding and maturation of the secretory and membrane proteins and lead to the accumulation of unfolded proteins in the ER lumen, interruption of lipid synthesis, and deregulation of cellular calcium levels [1,2]. The buildup of misfolded proteins in ER leads to the activation of the unfolded protein response (UPR), a multifunctional signaling pathway that either promotes cell recovery [3], or initiates cell death if the ER stress remains unmitigated [4]. The UPR signaling pathways are initiated by three ER transmembrane sensors: inositol-requiring protein 1 (IRE1), protein kinase RNAlike ER kinase (PERK) and activating transcription factor 6 (ATF6). IRE1 removes a 26-base intron from X-box-binding protein $1(X B P 1)$ mRNA in an unconventional splicing reaction that results in a translational frameshift that leads to the production of a functional and highly active spliced XBP1 (XBP1) transcription factor [5-9]. XBP1 enhances the expression of ER-resident chaperones and genes involved in ER-associated protein degradation (ERAD) [10] and promotes ER expansion [9]. The ER protein load is reduced by PERK-mediated phosphorylation of eIF $2 \alpha$ which inhibits 
most protein synthesis, by ER-associated degradation of misfolded proteins, and by IRE1-mediated mRNA cleavage and degradation [3]. However, if ER stress remains unmitigated, the UPR utilizes the same pathways to promote cell death by activating the intrinsic apoptotic pathways [11-16].

The interruption of the UPR transitions from prosurvival to apoptosis and the alteration of cell fate decisions contribute to the pathomechanisms of a number of human diseases including diabetes mellitus, cancer, and neurodegenerative and respiratory disorders [17]. To facilitate novel interventions for treating these disorders, it is important to understand the mechanisms governing the UPR pathways. Although we know the many of the details of the UPR pathways that contribute to cellular survival or apoptosis [18-20], it remains unclear how these signals determine the cell fate transitions in vivo. Understanding molecular mechanisms underlying UPR-related cell fate decisions is very challenging given that the experimental models rely on pharmacological ER stressors that are used at different concentrations and utilize divergent mechanisms for disturbing ER homeostasis [21-24]. Furthermore, previous studies have shown that UPR signaling has distinct consequences that ultimately depend on the nature and intensity of the stimulus as well as the specific cell type involved [18].

Although previous studies suggested that the transcriptional activity XBP1 is important in deciding cell fate in the UPR [25-30], the information regarding XBP1's direct role in modulating the transition between survival to apoptosis is limited. Therefore, the studies presented here were designed to select for XBP1-specific transcriptional targets and their roles in cell fate decisions. In our approach, we used inducible human cell lines that allowed for comparable and controlled expression of spliced XBP1 and unspliced XBP1 proteins. We also verified the identified XBP1-dependent genes with specific silencing of this transcription factor during mild pharmacological ER stress induction with both an N-linked glycosylation inhibitor (tunicamycin, Tm) as well as a non-competitive inhibitor of the sarco/endoplasmic reticulum $\mathrm{Ca}^{2+}$ ATPase (SERCA) (thapsigargin, Tg). Using next-generation sequencing (NGS) followed by bioinformatic analysis of XBP1-binding motifs, and validation using XBP1-specific silencing and quantitative real-time PCR (qRT-PCR), we defined an XBP1-dependent regulatory network and identified XBP1 as a repressor of both PUMA and IRE1 expression during the UPR. This approach not only confirmed previously known XBP1 roles during UPR, but also resulted in the identification of novel targets of this transcription factor that could fine-tune cell fate decisions. Furthermore, we show that XBP1 can modulate the PERK pathway activity via modulation of both $C H O P$ and growth arrest and DNA damage-inducible protein (GADD34) mRNA expression. Although further studies will be required to test the underlying molecular mechanisms involved in the relationship between these genes with XBP1, the studies presented here identify a novel regulatory role of XBP1 during the UPR.

\section{Materials and methods}

\section{Cell lines and culture conditions}

HeLa S3 cells were obtained from the American Type Culture Collection (CCL-2.2; Manassas, VA, USA). Cells were cultured in Minimum Essential Modified Eagle's Medium (Thermo Fisher Scientific, Waltham, MA, USA) with $2 \mathrm{mM}$ $l$-glutamine (MilliporeSigma, Burlington, MA, USA), antibiotics $(100 \mathrm{U} / \mathrm{ml}$ of penicillin and $100 \mu \mathrm{g} / \mathrm{ml}$ of streptomycin (MilliporeSigma), and 10\% fetal bovine serum in a humidified incubator at $37{ }^{\circ} \mathrm{C}$ in $5 \% \mathrm{CO}_{2}$ in 6-well plates. Cells were allowed to grow to $70-80 \%$ confluence before the start of the experiments. The culture conditions for the human Schwann cells (SNF96.2), human epidermal keratinocytes (HaCaT), 10 donor-pooled human umbilical vein endothelial cells (HUVEC), and human bronchial epithelial cells (16HBE14o-) were the same as previously described in [21,31].

The inducible HeLa S3 XBP1s and XBPIu cell lines were constructed beginning with vectors containing the cDNA sequences of XBP1s (NM_001079539.1) and XBP1u (NM_005080.3) that were obtained from GeneCopoeia (Rockville, MD, US; XBP1s cat. no. EX-Z4299 and XBP1u cat. no. EX-F0758). The ORFs sequences were verified with Sanger sequencing, and $X B P 1 s$ and XBPIu cDNAs were restricted with EcoRI/MluI and EcoRI/BamHI, respectively, and cloned into the pCW57-MCS1-P2A-MCS2 (Hygro) vector that permits doxycycline-controlled inducible lentiviral expression [32]. pCW57-MCS1-P2A-MCS2 (Hygro) was a gift from Adam Karpf (Addgene plasmid \# 80922; http:// n2t.net/addgene:80922). The correct pCW57-XBP1s and pCW57-XBPI $u$ insert sequences were verified with Sanger sequencing. These vectors along with VSV-G envelope expressing plasmid (pMD2.G) and lentiviral packaging plasmid (psPAX2) were used to transfect HEK-293 cells (ATCC CRL-1573) to generate lentiviruses carrying the $X B P 1 s$ or $X B P 1 u$ transgenes. The pMD2.G and psPAX2 plasmids were a gift from Didier Trono (Addgene plasmid \# 12259; http://n2t.net/addgene:12259 and Addgene plasmid \# 12260; $\mathrm{http}: / / \mathrm{n} 2 \mathrm{t}$.net/addgene:12260, respectively). The lentiviruses were also used to transduce Hela S3 cells [33, 34]. Finally, following hygromycin b selection $(300 \mu \mathrm{g} / \mathrm{ml}$, Sigma) and qPCR verification of $24 \mathrm{~h}$ doxycycline induction $(400 \mu \mathrm{g} / \mathrm{ml}$, D3072 MilliporeSigma) of XBP1s and XBP1 $u$ mRNAs in HeLa S3 cells, two stable clonal cell lines capable of stable inducible expression of XBP1s (Hela-XBP1s) and XBP1u $(\mathrm{HeLa}-X B P 1 u)$ were obtained. These cell lines were cultured 
in Minimum Essential Modified Eagle's Medium with $2 \mathrm{mM}$ $l$-glutamine, hygromycin B $(300 \mu \mathrm{g} / \mathrm{ml})$ and $10 \%$ tetracycline free fetal bovine serum (Takara Bio, USA) in a humidified incubator at $37{ }^{\circ} \mathrm{C}$ in $5 \% \mathrm{CO}_{2}$ in 6-well plates. Cells were allowed to grow to $70-80 \%$ confluence before the start of the experiments.

\section{Induction of ER stress and activation of the UPR}

Pharmacological induction of ER stress and activation of the UPR were performed as we previously described [21]. Briefly, cells were treated with the compounds for the time periods specified: tunicamycin (Tm 2.5 or $0.5 \mu \mathrm{g} / \mathrm{ml}$; Sigma, T7765), thapsigargin (Tg 50 or $2.5 \mathrm{nM}$; Sigma, T9033). CTRL cells were treated with vehicle CTRL, DMSO $(<0.5 \%$ v/v; Sigma, D2650). Furthermore, to verify IRE1 activity, cells treated were $20 \mu \mathrm{M} 4 \mu 8 \mathrm{C}$ (an IRE1 inhibitor, Sigma-Aldrich, SML0949) dissolved in DMSO (SigmaAldrich, St. Louis, MI, USA) [35].

\section{Real-time cell viability assay}

For real-time monitoring of cell viability, we applied the xCELLigence system as we described previously [36]. Briefly, HeLa cells $(12,000$ cells per well) were seeded in the 16-well PC plates (00300600890, ACEA Biosciences Inc., San Diego, CA, USA) $24 \mathrm{~h}$ prior to the experiment. CTRL cells were cultured in the presence of DMSO vehicle. Treated cells were incubated with ER stressors for the next $24 \mathrm{~h}$, and every $15 \mathrm{~min}$, the cell conductances (cell index) were recorded. All experiments were performed in triplicate with three independent repeats. RTCA software v. 1.2.1 (ACEA Biosciences, Inc, San Diego, CA, USA) was used to calculate the normalized cell index and the cell growth curve slopes.

\section{Monitoring caspase 3 and caspase 7 activity}

The caspase 7 is considered to be redundant with caspase 3 because these enzymes share an optimal peptide recognition sequence and have several endogenous protein substrates in common [37]. While our main goal was to assess caspase 3 activity, the commercially available assays do not distinguish between these two cysteine proteases. Hence, we applied the caspase-Glo 3/7 assay (Promega, Madison, WI, USA) to measure relative caspase activity as described previously [21, 36]. Briefly, cells the day after transfection with the specified siRNA were seeded onto 96-well luminescence assay white plates with clear bottoms (Corning Inc., 3903). The next day, the cells were treated with ER stressors or vehicle $(0.1 \%$ DMSO) for indicated time points. Following treatment, cells were washed with PBS and the Caspase-Glo 3/7 assays (Promega) were performed in accordance with the manufacturer's instructions using the GloMax-Multi + Detection System (Promega). The results were normalized to the values obtained from the vehicle control treatments.

\section{siRNA transfections}

siRNAs against $X B P 1$ (Ambion assay id s14915) and $B B C 3$ (Ambion assay id s25840) were purchased from Ambion. HeLa cells were transfected using the Lipofectamine RNAiMax (Invitrogen 13778030) according to manufacturer's protocol. The siRNAs were used at final concentrations of $30 \mathrm{nM}$. The transfected cells were cultured for 2 days prior to further analysis. Ambion siRNA Negative Control 1 (Ambion assay id MC22484) was used as a control.

\section{Isolation of RNA}

Total RNA (containing both mRNA and miRNA) was isolated using miRNeasy kit (Qiagen). RNA concentrations were calculated based on the absorbance at $260 \mathrm{~nm}$. RNA samples were stored at $-70{ }^{\circ} \mathrm{C}$ until use.

\section{Next-generation RNA sequencing analyses}

The RNA isolation and analyses were performed in HeLa$X B P 1 s$ and $-X B P 1 u$ cells. Briefly, following XBP1 induction with doxycycline ( $24 \mathrm{~h}$ and $400 \mu \mathrm{g} / \mathrm{ml}$ final concentration) total RNA isolation, samples were validated with qRT-PCR for ER stress activation prior to further analysis. Following rRNA depletion, the remaining RNA fraction was used for library construction and subjected to 100-bp single-end sequencing on an Illumina HiSeq 2000 instrument (San Diego, CA, USA). Sequencing reads were aligned to the Gencode human reference genome assembly (GRCh38 p7 Release 25) using STAR [38]. Transcript assembly and estimation of the relative abundance and tests for differential expression were carried out with Cufflinks and Cuffdiff [39]. The resulting data were validated with qRT-PCR. The heat map generation and hierarchical clustering were performed with the Morpheus Web server (https://software.broadinsti tute.org/morpheus). The Enrichr Web server (https://amp. pharm.mssm.edu/Enrichr/) [40] was applied to assign the NGS results into the 'Gene Ontology Biological Process' categories with the selection based on a False Discovery Rate $Q$-value $q<0.05$. Furthermore, the analyses were limited to experimentally verified interactions and no extended gene enrichment set analyses were performed.

\section{Measurement of mRNA quantitative real-time PCR (qRT-PCR)}

We used TaqMan One-Step RT-PCR Master Mix Reagents (Applied Biosystems) as described previously [41, 
42] using the manufacturer's protocol (retrotranscription: $15 \mathrm{~min}, 48^{\circ} \mathrm{C}$ ). For NGS data validation, 96 custom TaqMan expression array plates (id) were used according to the manufacturer's instructions. The relative expressions were calculated using the $2^{-\Delta \Delta \mathrm{Ct}}$ method [43] with the glyceraldehyde 3-phosphate dehydrogenase $(G A P D H)$, and neutral ribosomal phosphoprotein $\mathrm{PO}(R P L P O)$ genes as reference genes for the mRNA. TaqMan probes ids used are provided in Supplemental Table 1.

\section{Western blots}

The XBP1 protein detection was performed as described in [44]. Briefly, cells were lysed on ice for $15 \mathrm{~min}$ in RIPA buffer [150 mM NaCl, 1\% NP-40, $0.5 \%$ sodium deoxycholate, $0.1 \% \mathrm{SDS}$, and $50 \mathrm{mM}$ Tris- $\mathrm{HCl}(\mathrm{pH} 8.0)$ ] supplemented with Protease Inhibitor Complete Mini (000000011836170001; Roche, Basel, Switzerland). The insoluble material was removed by centrifugation at $15,000 \mathrm{~g}$ for $15 \mathrm{~min}$. Protein concentrations were determined by Bio-Rad Protein Assay [Bradford-based method; Bio-Rad, Hercules, CA, USA] using bovine serum albumin (BSA; MilliporeSigma) as the standard. Following the normalization of protein concentrations, lysates were mixed with an equal volume of 2 times Laemmli sample buffer (Bio-Rad) and incubated for $5 \mathrm{~min}$ at $95^{\circ} \mathrm{C}$ before separation by SDSPAGE on stain-free TGX gradient gels (Bio-Rad). Following SDS-PAGE, the proteins were transferred to PVDF membranes (300 $\mathrm{mA}$ for $90 \mathrm{~min}$ at $4{ }^{\circ} \mathrm{C}$ ). The membranes were then blocked with BSA dissolved in PBS and Tween-20 (3\% BSA and $0.5 \%$ Tween-20) for $1-2 \mathrm{~h}$ followed by immunoblotting with the primary antibody for each experiment for spliced XBP1 (mAb 12782; diluted at 1:1000; Cell Signaling Technology, Danvers, MA, USA) or unspliced XBP1 (NBP1-77681; diluted at 1:700; Novus Biological USA). The unsliced XBP1 antibody has been independently validated with siRNA against XBP1 (Supplemental Figure S1). For PUMA, the monoclonal antibody MBS9131466 (MyBioSource Inc. San Diego, CA USA) was used for overnight incubations at 1:1500 dilution. For IRE1 (phosphor-S724), the monoclonal antibody ab243665 (Abcam, USA) was used at incubations at 1:1000 dilution. After the washing steps, the membranes were incubated with goat anti-rabbit $\mathrm{IgG}$ $(\mathrm{H}+\mathrm{L})$ horseradish peroxidase-conjugated secondary antibodies (Bio-Rad) and detected using ECL (Amresco, Solon, $\mathrm{OH}, \mathrm{USA}$ ). Densitometry was performed using Image Lab software v.4.1 (Bio-Rad).

\section{XBP1 motif analysis}

The promoters of the gene transcripts that were affected by $X B P 1$ induction in the NGS experiments were analyzed for XBP1-binding sites. In each gene promoter sequence that was defined as a $20 \mathrm{~kb}$ window around the TSS, we examined only the open chromatin regions that were established in the HeLa S3 cell line by the ENCODE [45] project. We merged both DNase I-seq HeLa datasets found in Ensembl (v.79) [46]. We used the Nencki Genomics Database (v. 79_1) [47] to obtain genomic coordinates of these motif instances. For each gene, we calculated the number of instances found in the open chromatin regions.

\section{Statistical analysis}

Results were expressed as a mean \pm standard deviation. Statistical significance was determined using the Student's $t$-test and ANOVA on ranks with $P$ values $P \leq 0.05$ considered significant. The correlation was accessed via the Pearson product-moment correlation method.

\section{Results}

Since our working hypothesis was that the commonly used concentrations of ER stressors lead to non-physiological elevation of UPR signals and the potential for misassignment of UPR pathways targets or their role in cell fate decisions, we compared commonly used classical pharmacological stressors at high concentrations (high stress) and at low concentrations (low stress). We tested a glycosylation inhibitor tunicamycin (Tm) that is normally used at $2.5 \mu \mathrm{g} / \mathrm{ml}$ and a non-competitive inhibitor of the sarco/endoplasmic reticu$\operatorname{lum} \mathrm{Ca}^{2+}$ ATPase thapsigargin (Tg) that is normally used at $50 \mathrm{nM}$ (high stress). For the low-stress model, we used Tm at $0.5 \mu \mathrm{g} / \mathrm{ml}$ and $\mathrm{Tg}$ at $2.5 \mathrm{nM}$. These concentrations were determined experimentally as the lowest concentrations that were able to induce XBP1, HSPA5 (BiP) and DITT3 (also known as $C H O P$ ) mRNAs by at least twofold after $6 \mathrm{~h}$ of treatment. We used HeLa cells since this is a common model system that has been employed in ER stress and UPR studies [48-51].

As shown in Fig. 1, both stress models were able to induce both prosurvival (HSPA5, XBP1s and DNAJB9) and apoptotic (DDIT3) reporters. The adaptive BiP chaperone mRNA levels (HSPA5) was continuously elevated in both the high and low-stress models (Fig. 1A). High ER stress was effectively induced with the commonly used Tm and Tg concentrations $(2.5 \mu \mathrm{g} / \mathrm{ml}$ and $50 \mathrm{nM}$, respectively) [21, 44, 49]. High stress resulted in a 10and 15-fold induction of HSPA5 mRNA with Tm and Tg, respectively, after $6 \mathrm{~h}$ and remained elevated after $12 \mathrm{~h}$ of treatment. In contrast, during mild ER stress conditions after $6 \mathrm{~h}$, the HSPA5 mRNA was induced by $\sim$ threefold by both $\mathrm{Tm}$ and $\mathrm{Tg}$, and this dramatically increased after $12 \mathrm{~h}$ of treatment (Fig. 1A). The proapoptotic DDIT3 (CHOP) mRNA levels were also elevated 18- and 6-fold with Tm 

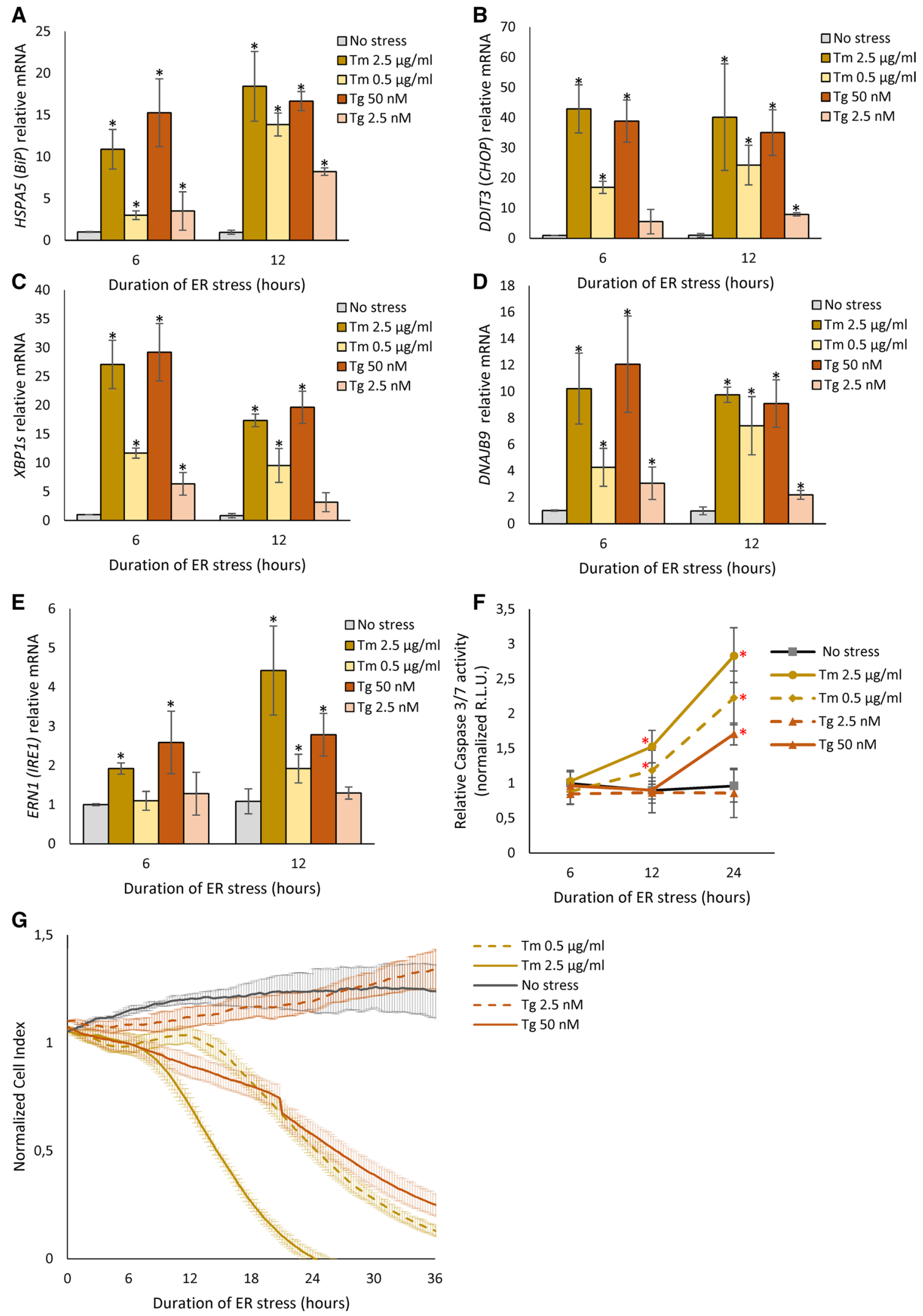
४Fig. 1 ER stress-induced changes in A $B I P$, B $C H O P$, C XBP1s, D $D N A J B 9$, and $\mathbf{E} I R E 1 \mathrm{mRNA}$ levels in HeLa cells. The results from three independent experiments $(n=9)$ are plotted normalized to $G A P D H$ and RPLPO mRNA levels and expressed as a fold change over the no-stress controls. Error bars represent standard deviations. Significant changes $(P$ value $P<0.05)$ are marked with an asterisk. ER stressors used: $\mathrm{Tm}(2.5 \mu \mathrm{g} / \mathrm{ml}), \mathrm{Tm}(0.5 \mu \mathrm{g} / \mathrm{ml}), \mathrm{Tg}(50 \mathrm{nM}))$ and $\mathrm{Tg}(2.5 \mathrm{nM})$. F HeLa cells were treated with ER stressors $((2.5 \mu \mathrm{g} /$ $\mathrm{ml}), \mathrm{Tm}(0.5 \mu \mathrm{g} / \mathrm{ml}), \mathrm{Tg}(50 \mathrm{nM})$ and $\mathrm{Tg}(2.5 \mathrm{nM}))$ for time points specified. The caspase $3 / 7$ activity was monitored by luminescence and expressed in relative light units (RLU). Cells for each time point were seeded in triplicate, and the experiments repeated three times. Error bars represent standard deviations. G The cell conductances (expressed as normalized cell index) were accessed every $15 \mathrm{~min}$ following a 36-h treatment with $\mathrm{Tm}(2.5 \mu \mathrm{g} / \mathrm{ml}), \mathrm{Tm}(0.5 \mu \mathrm{g} / \mathrm{ml}), \mathrm{Tg}$ $(50 \mathrm{nM})$ and $\mathrm{Tg}(2.5 \mathrm{nM})$. DMSO was used in the no-stress conditions (CTRL). The conductances were normalized to the last value prior to experiment start. Representative results from three independent experiments measurements $(n=9)$ are plotted

and $\mathrm{Tg}$ treatment, respectively, after $6 \mathrm{~h}$ of low-stress conditions and remained elevated after $12 \mathrm{~h}$ (Fig. 1B). The use of the higher concentrations of $\mathrm{Tm}$ and $\mathrm{Tg}$ resulted in $\sim 40$ - and $\sim 35$-fold inductions of DDIT3 (CHOP) mRNA expression after both 6 and $12 \mathrm{~h}$. A similar pattern of high- and low-stress treatments was seen with $X P B 1 s$ (Fig. 1C) and DNAJB9 (Fig. 1D) mRNAs in that they were induced less during the low-stress conditions as might be expected. Interestingly, the XBP1s mRNA levels decreased after $12 \mathrm{~h}$, whereas all the other mRNAs either increased or remained the same after high- and low-stress conditions. The DNAJB9 (DnaJ heat shock protein family (Hsp40) member B9) mRNA levels, a pro-adaptive chaperone and an XBP1 transcriptional target, were elevated as expected under both high- and low-stress conditions (Fig. 1D). Furthermore, ERNI (IRE1) mRNA expression was induced after $6 \mathrm{~h}$ only by higher Tm and Tg concentrations, whereas in mild stress, ERN1 mRNA was only elevated by $\mathrm{Tm}$ treatment after $12 \mathrm{~h}$ (Fig. 1E).

We next tested the effects of high and low stress on cell viability and proliferation. As shown in Fig. 1F, the Tm treatments at high- and low-stress conditions elevated caspase 3/7 activity at 12 and $24 \mathrm{~h}$, whereas the Tg treatment elevated the caspase activity only at $24 \mathrm{~h}$ during high stress conditions (Fig. 1F). The lack of significant apoptotic signal for the lower $\mathrm{Tg}$ concentration was consistent with the lower induction of apoptotic mRNAs. These observations were also consistent with the results of real-time monitoring of HeLa cell proliferation (Fig. 1G). The mild ER Tg-induced stress had no significant effect on HeLa proliferation up to $36 \mathrm{~h}$, while treatment with higher Tg concentration significantly limited cell growth throughout the entire time course. Whereas, both Tm concentrations affected HeLa growth and demonstrated a clear indication of apoptosis after $18 \mathrm{~h}$ (Fig. 1G). Taken together, the data illustrate that lower stress conditions still activate the UPR and may provide a more physiological model to delineate the differences between the adaptive and apoptotic UPR signaling pathways.

To follow XBP1's role in the UPR, we created an inducible HeLa cell line model in which we could express low mRNA levels of this transcription factor that might mimic the levels observed during mild ER stress. Following the expansion and validation of individual clones expressing $X B P 1 s$ under an inducible promoter, we selected a cell line that upon induction, stably expressed about an 11-fold increase XBP1s mRNA (HeLa-XBP1s) when compared to noninduced cells (Fig. 2A). The obtained XBP1 levels were sufficient to induce the expression of DNAJB9 mRNA, an XBP1 transcriptional target gene (Fig. 2B). In this case, the $D N A J B 9$ mRNA was induced only about 1.5 -fold, whereas in the corresponding ER stress model the DNAJB9 expression was higher (about 3-4-fold), suggesting that other transcriptional mechanisms may be responsible for this gene induction during UPR. The levels of XBP1s mRNA induction resulted in XBP1 protein levels (Fig. 2C) comparable to those observed after $6 \mathrm{~h}$ of ER stress-induced with $2.5 \mu \mathrm{g} /$ $\mathrm{ml} \mathrm{Tm}$ and about half of the protein levels observed with $50 \mathrm{nM} \mathrm{Tg}$ (Fig. $2 \mathrm{EF}$ ), despite the fact that both of these stressors induced XBP1s mRNA comparably (Fig. 1C). The exogenous XBP1 signals were independent of IRE1 activity since $4 \mu 8 \mathrm{C}$, a specific IRE1 activity inhibitor, had no effect on the induced XBP1s mRNA levels [52] (Fig. 2G). Furthermore, the XBP1 induction did not lead to accumulation of XBP1 u mRNA (Fig. 2H). Notably, in the presence of doxycycline, the XBP1 protein was stably expressed up to a week (Supplemental Figure S2AB), showing a trend to accumulate after a prolonged time of induction. Finally, the doxycycline used for the induction of XBP1s did not induce ER stress (Supplemental Figure S2C) and siRNA knockdown of $X B P 1 s$ mRNA induction with the inducible cell line dramatically reduced the XBP1s mRNA levels (Supplemental Figure S2D).

In our analysis of XBP1-affected factors, we obtained RNA samples from the HeLa-XBP1s cell line under control conditions (no induction) and after $24 \mathrm{~h}$ of induction, and subjected both to RNA-seq analysis. Notably in these NGS analysis, inductions of all XBPI isoform mRNAs were accessed as a one $X B P 1$ gene change and in the range of fivefold and that is reflected by about $2 \log 2$ fold change. The isoform-dedicated analysis, however, indicated that the $X B P 1 s$ mRNA induction was about 20-fold. In this analysis, we focused only on genes that were specifically affected by induction by at least a log-fold (twofold change) and had a $P$ value below 0.05 .

We were aware that by applying such "loose" selection parameters, however, would result in a large group of genes. Given this concern, we performed independent validations of the XBP1 predicted targets. Furthermore, given the large number of identified genes fulfilling this criterion could 

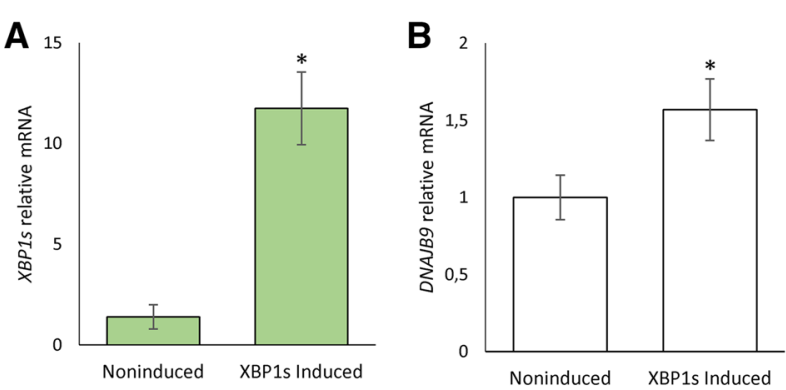

E

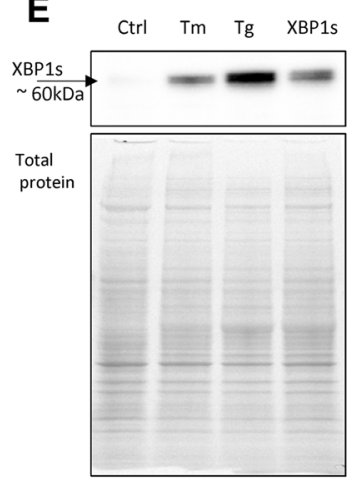

$\mathbf{F}$
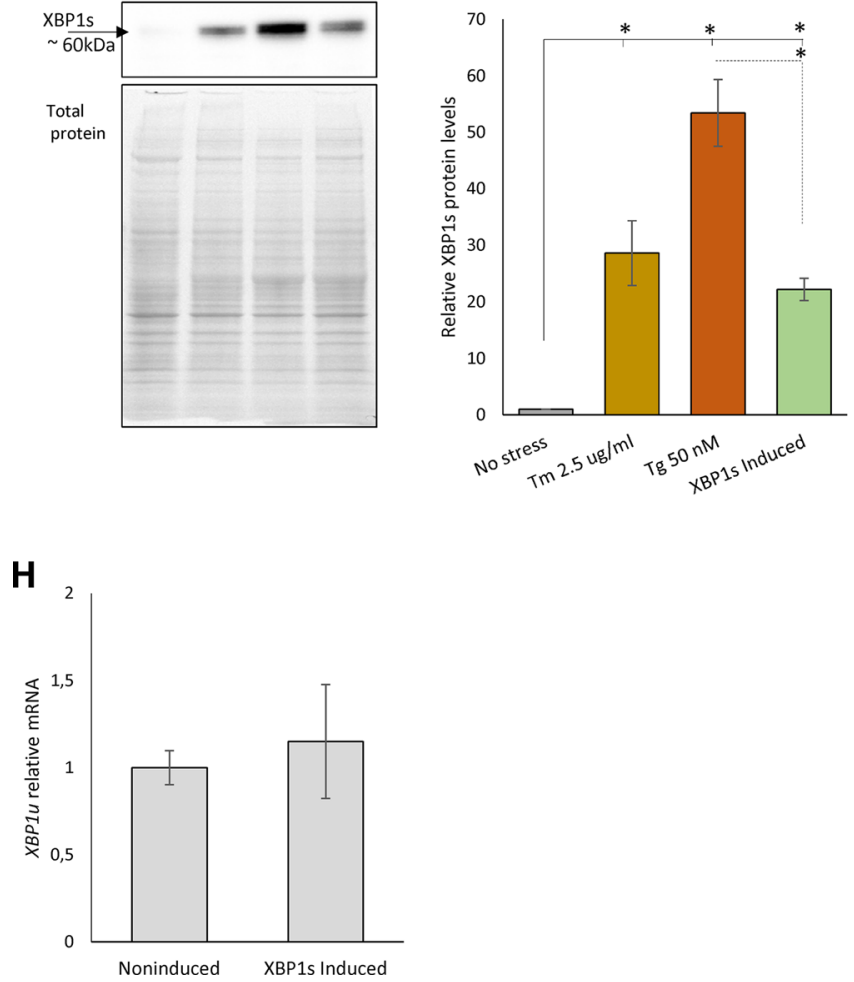

Fig. 2 The HeLa-XBP1s cell line induced for $24 \mathrm{~h}$ accumulates A $X B P 1$ (green) and B DNAJB9 (white) mRNA. The results from three independent experiments $(n=9)$ are plotted normalized to GAPDH and RPLPO mRNA levels and expressed as a fold change over the noninduced cells. Error bars represent standard deviations. Significant changes $(P$ value $P<0.05)$ are marked with an asterisk. The corresponding changes in XBP1 protein levels were evaluated by Western blot $(\mathbf{C})$ normalized to total protein levels $(\mathbf{D})$ and related noninduced control or evaluated by Western blot and to compared to ER stress induced by $\mathrm{Tm}(2.5 \mu \mathrm{g} / \mathrm{ml}$, brown $) \mathrm{Tg}(50 \mathrm{nM}$, red $)$ treatment for $6 \mathrm{~h}(\mathbf{E})$ and related to the no-stress control $(\mathbf{F}) .{ }^{*} P<0.05$

also result from the doxycycline treatment. As a control, therefore, the RNA-seq data obtained from a comparable inducible HeLa cell line expressing low levels of XBP $1 u$ $(\mathrm{HeLa}-X B P 1 u)$ were examined. These induced genes were omitted from further analysis. As previously mentioned, $X B P 1 s$ mRNA results from ER stress-activated IRE1 splicing of a $26 \mathrm{nt}$ unconventional intron in the coding region
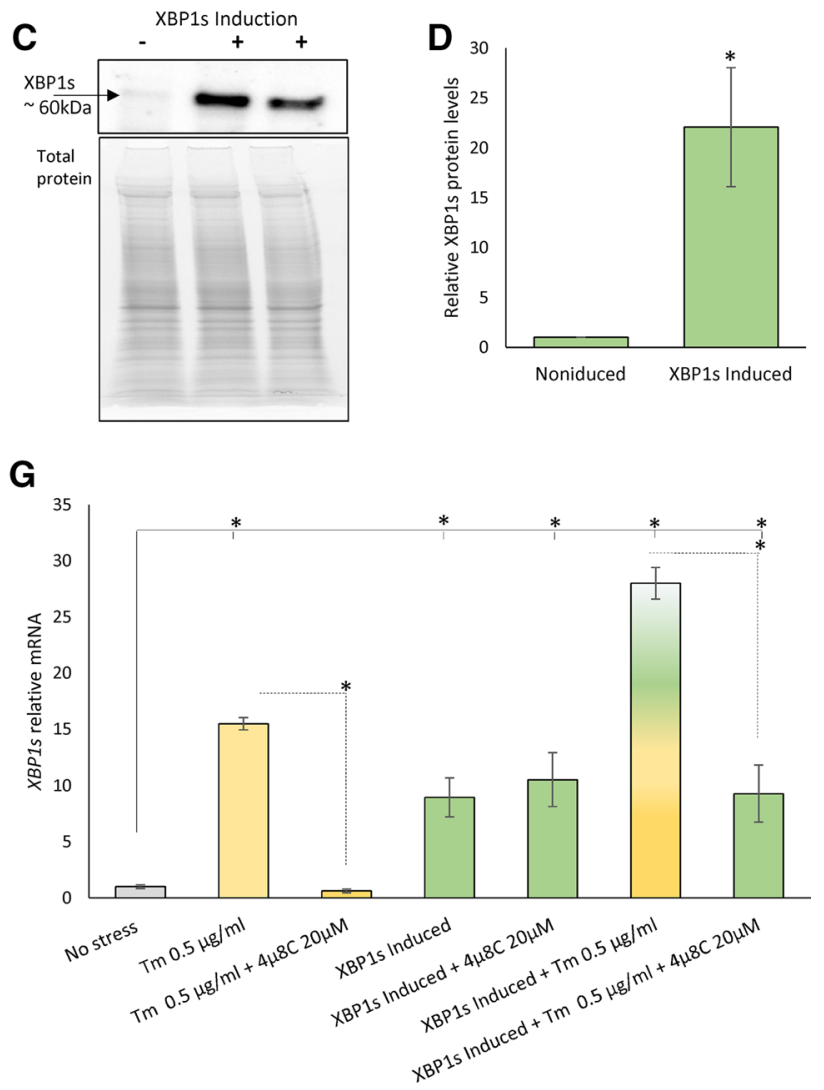

was considered significant. G The exogenous $X B P 1 s$ mRNA levels were independent IRE1 activity as shown with $4 \mu 8 \mathrm{C}(20 \mu \mathrm{M})$, a specific IRE1 activity inhibitor. The yellow-green bars depict the conditions where XBP1s expression was induced in the presence of Tm and $4 \mu 8 \mathrm{C}$. Tm was used at $0.5 \mu \mathrm{g} / \mathrm{ml}$ concentration for $6 \mathrm{~h}$ (yellow). H The exogenous $X B P 1 s$ expression does not lead to the accumulation of XBPlu mRNA (grey). The results from three independent experiments $(n=9)$ are plotted normalized to $G A P D H$ and $R P L P O$ mRNA levels and expressed as a fold change over the noninduced cells. Error bars represent standard deviations. Significant changes $(P$ value $P<0.05$ ) are marked with an asterisk

of unspliced $X B P 1(X B P 1 u)$ that causes a frameshift. The XBP1 protein $(\sim 48 \mathrm{kDa})$ has the same $\mathrm{N}$-terminus, but a longer and distinct $\mathrm{C}$-terminus compared to the unspliced XBP1 protein ( 29 kDa) [5, 53]. More importantly, the new $\mathrm{C}$-terminus in XBP1 contains the transactivation domain [5, 53]. The induction levels of $X B P 1 u$ mRNA in these cells were in the tenfold range that did result in unspliced XBP1 
A

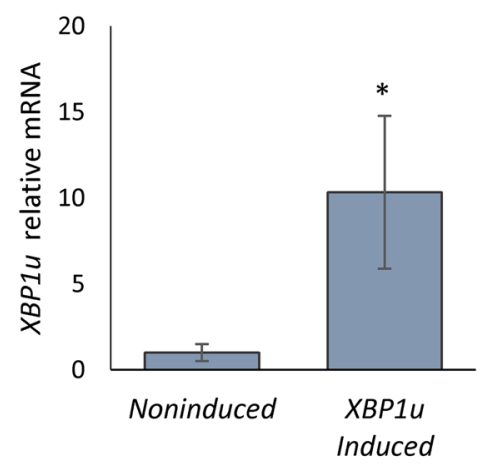

B
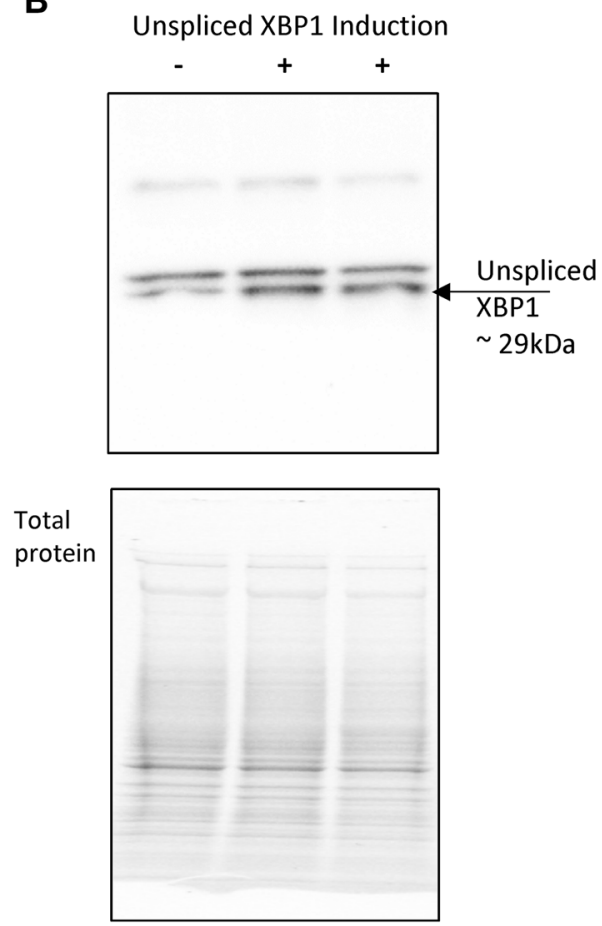

C

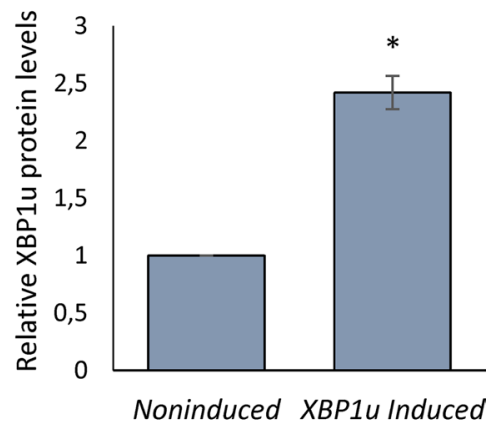

D

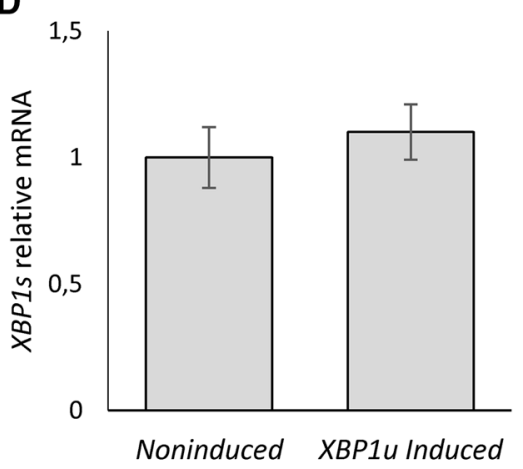

E

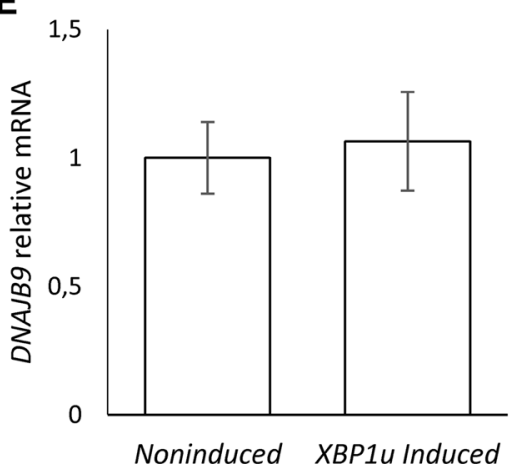

Fig. 3 Upon 24-h induction, the HeLa-XBP1u cell line accumulates $X B P 1 u$ mRNA. A The results from three independent experiments $(n=9)$ are plotted normalized to $G A P D H$ and RPLPO mRNA levels and expressed as a fold change over the noninduced cells. Error bars represent standard deviations. Significant changes $(P$ value $P<0.05)$ are marked with an asterisk. The corresponding changes in unspliced XBP1 protein levels were evaluated by Western blot $(\mathbf{B})$ normalized to total protein levels $(\mathbf{C})$ and related noninduced control. $* P<0.05$

protein expression (Fig. 3A-C) but did not result in XBP1s mRNA accumulation (Fig. 3D) or any increase in XBP1 transcriptional activity (Fig. 3E) or protein (Supplemental Figure S1B). The unspliced XBP1 protein levels are in agreement with previous reports that this protein is rapidly degraded [54]. Furthermore, XBP1 $u$ induction was performed under no ER stress conditions to avoid the possibility of a negative impact of unspliced XBP1 protein on spliced XBP1 [55]. Given this, the RNA-seq data obtained from the was considered significant. The exogenous $X B P 1 u$ expression does not lead to the accumulation of XBP1s (D) and DNAJB9 (E) mRNA. The results from three independent experiments $(n=9)$ are plotted normalized to GAPDH and RPLPO mRNA levels and expressed as a fold change over the noninduced cells. Error bars represent standard deviations. Significant changes $(P$ value $P<0.05)$ are marked with an asterisk

induced HeLa-XBPI $u$ cell line were an appropriate control for our experiments.

The overlap of the RNA-seq data obtained from induced spliced XBP1 and unspliced XBP1 expression systems is illustrated in a Venn diagram in Fig. 4A. The functional assignment of XBP1 modulated genes was performed with Enrichr Web server using a strict criterion $(P$ value $P<0.05$ and $q$ value $q<0.05)$. As shown in Fig. 4B, this analysis of expression profiles specific for cells expressing 


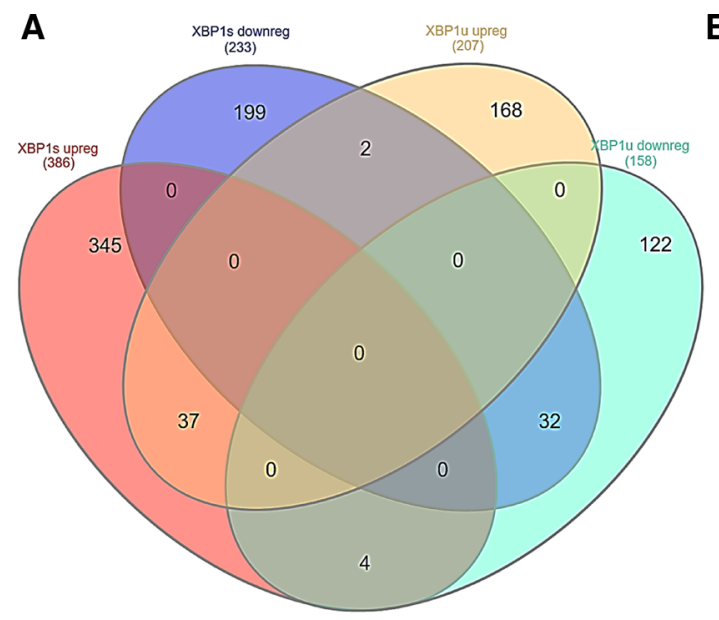

B

$X B P 1 s$

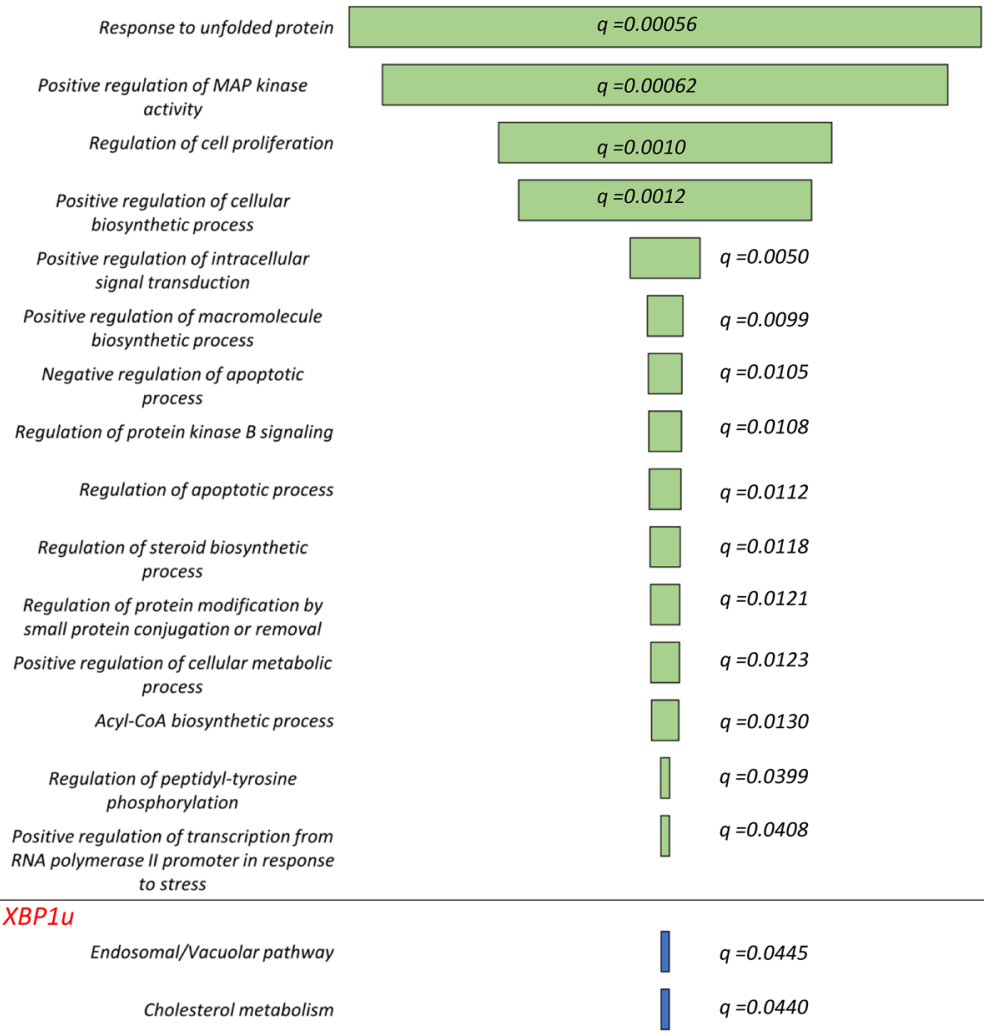

Fig. 4 The impact of the exogenic XBPIu and XBP1s induction on HeLa genome-wide cellular mRNA profiles and their potential functional consequences. A The Venn diagram [56] represents the general distribution of mRNAs that were significantly $(\mathrm{P}<0.05)$ affected by $X B P 1 s$ and XBP $1 u$ transgenes-Supplemental Table 2C. B Transcripts reduced and induced upon XBP1 induction are marked with dark blue and red, respectively, whereas mRNAs reduced and induced upon unspliced XBP1 induction are marked with light blue and yellow, respectively. The Gene Ontology assignment of the cellular functions of mRNAs potentially regulated by the spliced XBP1 (XBP1s) or unspliced XBP1 (XBP1u) as assigned by the Enrichr Web serverSupplemental Table 2D [40]. The green bar color depicts the $q$ value less than 0.05 . The longer bars have the lower $q$ values
$X B P 1 u$ did not revealed any specific activation of ER stress, UPR signaling or apoptotic pathways. Nevertheless, some of the unspliced XBP1-related expression changes could be assigned to cholesterol metabolism and the endosomal pathway. Furthermore, analysis of genes that were common between spliced and unspliced XBP1 mRNA expression profiles did not result in any significant functional assignment. Notably, because of XBP1s induction, the mRNA of 345 and 199 genes were induced or reduced, respectively. Furthermore, this expression profile correlated well with changes related to the UPR that included protein folding, cellular proliferation, and negative regulation of apoptotic pathways (Fig. 4B).

Given that XBP1's impact on gene expression can result from both direct and indirect effects with transcription factors originating from the other UPR branches (PERK and ATF6), we decided to narrow our verification set to the genes that contained potential promoter regions for XBPI.
To verify the potential direct role of XBP1 during the UPR, the identified gene locations were analyzed for the presence of XBP1-binding motifs (Fig. 5A). Our analysis was in HeLa cells, and we focused only on transcriptionally active chromatin regions.

This resulted in the selection of 58 genes potentially directly regulated by spliced XBP1 that were then validated in 3 independent biological replicates using 96-well qPCR arrays (Supplemental Table 2AB). The expression changes were accessed following XBP1 overexpression as well as silencing with specific siRNA against $X B P 1$ during $6 \mathrm{~h}$ of mild ER stress (induced with $\mathrm{Tm}$ or $\mathrm{Tg}$ ). Furthermore, in our validation set, we included HSPA5 $(B i P)$ and DDIT3 $(C H O P)$ mRNAs that were previously also reported to be regulated by XBP1 [57]. Interestingly, the $C H O P$ region did not contain any potential XBP1-binding motifs, whereas in $B i P$ there were 11 sites. This approach identified significant changes in 40 of the transcripts (Table 1). 
A

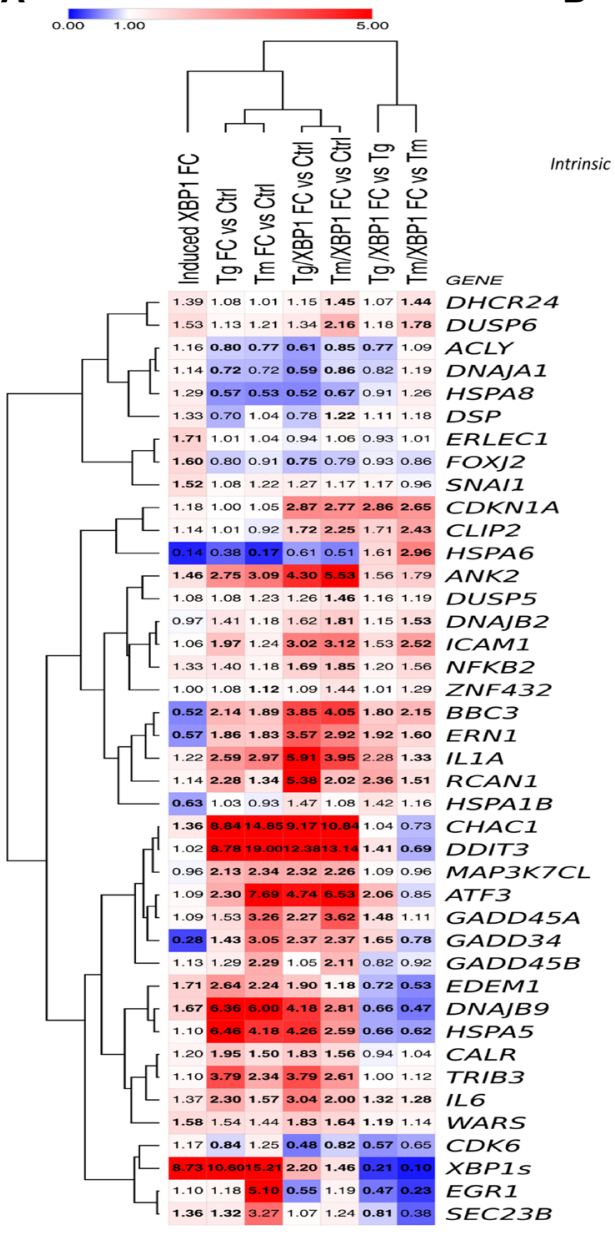

B

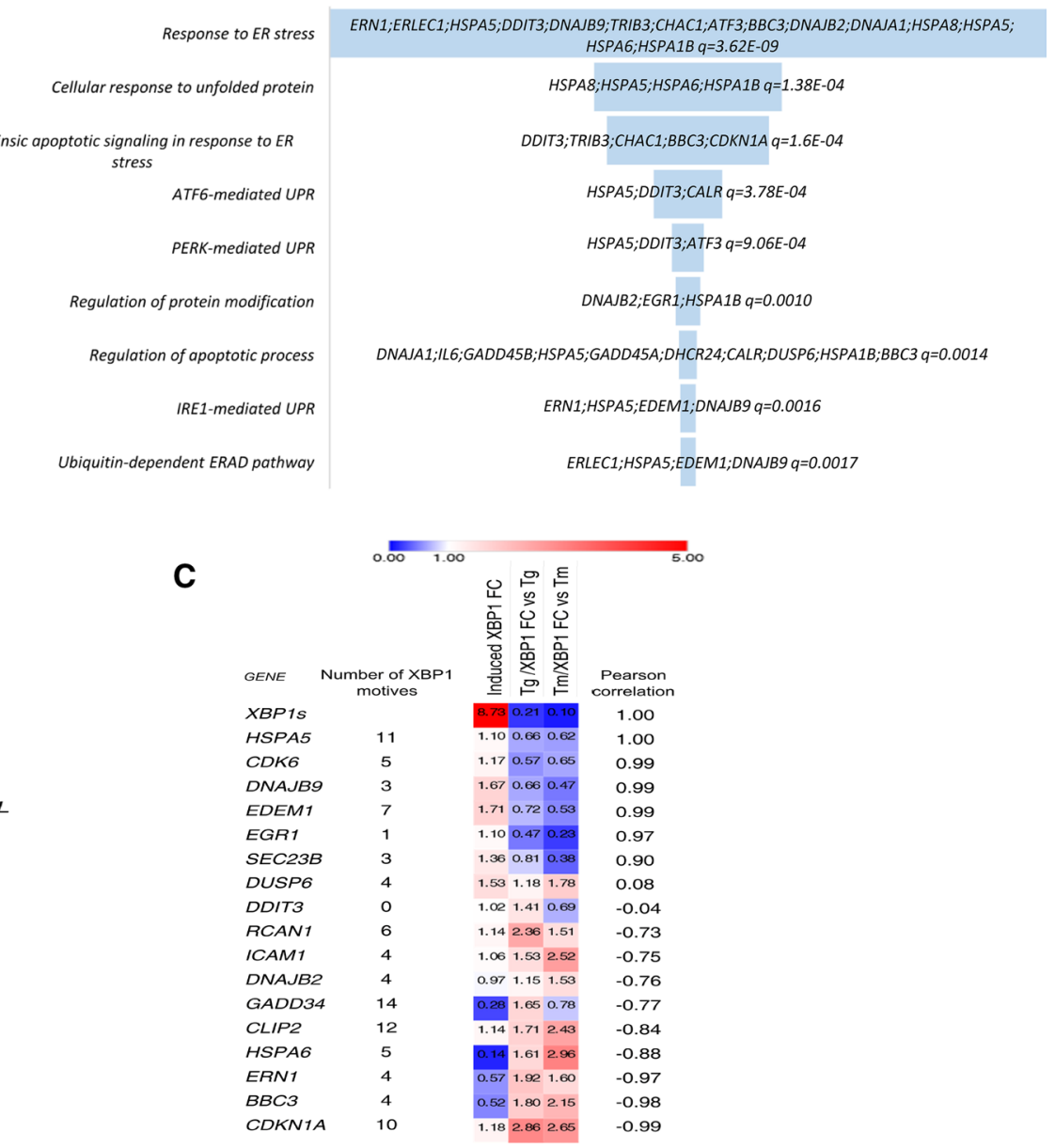

Fig. 5 The heat map representing expression changes of all verified potentially XBP1-dependent genes identified in induced XBP1s expression experiments (Induced XBP1) and separately in silencing $X B P 1$ during mild stress experiments in HeLa cells $(\mathrm{Tg} / \mathrm{XBP} 1 \mathrm{~s}$ and Tm/XBP1s). A The logo of XBP1-binding motif M00402 (consensus: GACGTGkCmtww, where $k=G$ or $T ; m=A$ or $C ; w=A$ or $T)$ from the Hocomoco v. 9 motif library. B Heat maps were generated and organized according to hierarchical clustering of expression changes with the Morpheus software (Morpheus, https://softw are.broadinstitute.org/morpheus). C FC depicts "fold change",

As shown in Table 1 and Supplemental Table 2A, we observed that following XBP1s induction, 8 mRNAs were significantly induced that included ankyrin 2 (ANK2), glutathione-specific gamma-glutamylcyclotransferase 1 (CHAC1), ER-Resident Protein ERdj4, DNAJB9, ER degradation-enhancing alpha-mannosidase-like protein 1 (EDEM1), ER lectin 1 (ERLECI), forkhead box J2 (FOXJ2), $S E C 23 B$, and interferon-induced protein 53 (WARS). Notably, ERLEC1, WARS and SEC23B have been previously identified as XBP1-dependent genes in MCF-7 and HEK293 cells [58, 59], whereas $C H A C 1$ has been identified recently as an important regulator of UPR-associated ferroptosis [60]. Furthermore, 5 mRNAs were significantly
Tm-tunicamycin $0.5 \mu \mathrm{g} / \mathrm{ml}$ induced ER stress for $6 \mathrm{~h}, \mathrm{Tg}$ - thapsigargin $2.5 \mathrm{nM}$ induced ER stress for $6 \mathrm{~h}$, whereas Tm/XBP1 S and $\mathrm{Tg} / \mathrm{XBP} 1 \mathrm{~S}$ depict $X B P 1$ silencing in each of these stress models. D The Enrichr Web server (https://amp.pharm.mssm.edu/Enrichr/) was applied to assign the qPCR results into the "Gene Ontology Biological Process" categories with a selection based on a $q$ value $q<0.05$. Heat map representing the mRNAs that display the most correlated changes with XBP1s mRNA levels as calculated by Pearson correlations

reduced upon $X B P 1 s$ induction and included (1) IREI (ERN1), (2) growth arrest and DNA damage-inducible protein (GADD34) [61], a crucial PERK pathway regulator, (3) PUMA (BBC3), an important ER stress-related proapoptotic factor [62]), (4) heat shock protein family A (Hsp70) member $1 B(H S P A 1 B)$, and (5) heat shock protein family A (Hsp70) member 6 (HSPA6).

In the parallel $X B P 1$-silencing experiments (Table 1 and Supplemental Table 2B), we observed that mRNA levels of well-known XBP1 targets such as DNAJB9 and EDEM1 $[44,57]$ as well as interleukin 6-IL6 [63] were significantly induced by both stressors and reduced upon $X B P 1$ silencing. In addition, as previously reported, $X B P 1$ silencing had a 
Table 1 Summary of mRNA changes observed during XBP1s induction, ER stress-induced with $\mathrm{Tg}$ or Tm, and Tg or Tm ER stress together with $X B P 1$ silencing $(T g$ and $T \mathrm{~m} / X B P 1 \mathrm{~S})$

\begin{tabular}{|c|c|c|c|c|c|c|c|c|}
\hline Gene & $\begin{array}{l}\text { Number of } \\
\text { XBP1 motifs }\end{array}$ & $\begin{array}{l}\text { Induced } \\
X B P 1 s \text { FC }\end{array}$ & Tg FC vs Ctrl & $\begin{array}{l}\mathrm{Tg} / \mathrm{XBP} 1 \mathrm{~S} \\
\mathrm{FC} \text { vs Ctrl }\end{array}$ & $\begin{array}{l}\mathrm{Tg} / \mathrm{XBP} 1 \mathrm{~S} \\
\mathrm{FC} \text { vs Tg }\end{array}$ & Tm FC vs Ctrl & $\begin{array}{l}\text { Tm/XBP1 S } \\
\text { FC vs Ctrl }\end{array}$ & $\begin{array}{l}\text { Tm/XBP1 S } \\
\text { FC vs Tm }\end{array}$ \\
\hline$A C L Y$ & 1 & 1.15 & 0.80 & 0.61 & 0.77 & 0.77 & 0.85 & 1.09 \\
\hline ANK2 & 1 & 1.45 & 2.75 & 4.30 & 1.56 & 3.09 & 5.53 & 1.79 \\
\hline ATF3 & 6 & 1.09 & 2.30 & 4.74 & 2.06 & 7.69 & 6.53 & 0.85 \\
\hline$B B C 3$ & 4 & 0.51 & 2.14 & 3.85 & 1.80 & 1.89 & 4.05 & 2.15 \\
\hline$C A L R$ & 14 & 1.19 & 1.95 & 1.83 & 0.94 & 1.50 & 1.56 & 1.04 \\
\hline$C D K 6$ & 5 & 1.17 & 0.84 & 0.48 & 0.57 & 1.25 & 0.82 & 0.65 \\
\hline$C D K N 1 A$ & 10 & 1.18 & 1.00 & 2.87 & 2.86 & 1.05 & 2.77 & 2.65 \\
\hline CHACl & 1 & 1.36 & 8.84 & 9.17 & 1.04 & 14.85 & 10.84 & 0.73 \\
\hline DDIT3 & 0 & 1.02 & 8.78 & 12.38 & 1.41 & 19.00 & 13.14 & 0.69 \\
\hline CLIP2 & 12 & 1.13 & 1.01 & 1.72 & 1.71 & 0.92 & 2.25 & 2.43 \\
\hline DHCR24 & 2 & 1.39 & 1.08 & 1.15 & 1.07 & 1.01 & 1.45 & 1.44 \\
\hline DNAJA1 & 4 & 1.13 & 0.72 & 0.59 & 0.82 & 0.72 & 0.86 & 1.19 \\
\hline$D N A J B 2$ & 4 & 0.96 & 1.41 & 1.62 & 1.15 & 1.18 & 1.81 & 1.53 \\
\hline DNAJB9 & 3 & 1.67 & 6.36 & 4.18 & 0.66 & 6.00 & 2.81 & 0.47 \\
\hline$D S P$ & 2 & 1.33 & 0.70 & 0.78 & 1.11 & 1.04 & 1.22 & 1.18 \\
\hline DUSP5 & 12 & 1.08 & 1.08 & 1.26 & 1.16 & 1.23 & 1.46 & 1.19 \\
\hline DUSP6 & 4 & 1.52 & 1.13 & 1.34 & 1.18 & 1.21 & 2.16 & 1.78 \\
\hline EDEM1 & 7 & 1.71 & 2.64 & 1.90 & 0.72 & 2.24 & 1.18 & 0.53 \\
\hline$E G R 1$ & 1 & 1.09 & 1.18 & 0.55 & 0.47 & 5.10 & 1.19 & 0.23 \\
\hline$E R L E C 1$ & 6 & 1.70 & 1.01 & 0.94 & 0.93 & 1.04 & 1.06 & 1.01 \\
\hline ERN1 & 4 & 0.56 & 1.86 & 3.57 & 1.92 & 1.83 & 2.92 & 1.60 \\
\hline FOXJ2 & 4 & 1.59 & 0.80 & 0.75 & 0.93 & 0.91 & 0.79 & 0.86 \\
\hline$G A D D 45 A$ & 2 & 1.08 & 1.53 & 2.27 & 1.48 & 3.26 & 3.62 & 1.11 \\
\hline$G A D D 45 B$ & 2 & 1.12 & 1.29 & 1.05 & 0.82 & 2.29 & 2.11 & 0.92 \\
\hline$H S P A 1 B$ & 13 & 0.63 & 1.03 & 1.47 & 1.42 & 0.93 & 1.08 & 1.16 \\
\hline HSPA5 & 11 & 1.10 & 6.46 & 4.26 & 0.66 & 4.18 & 2.59 & 0.62 \\
\hline HSPA6 & 5 & 0.13 & 0.38 & 0.61 & 1.61 & 0.17 & 0.51 & 2.96 \\
\hline HSPA & 1 & 1.29 & 0.57 & 0.52 & 0.91 & 0.53 & 0.67 & 1.26 \\
\hline ICAMI & 4 & 1.06 & 1.97 & 3.02 & 1.53 & 1.24 & 3.12 & 2.52 \\
\hline ILIA & 3 & 1.21 & 2.59 & 5.91 & 2.28 & 2.97 & 3.95 & 1.33 \\
\hline IL6 & 4 & 1.37 & 2.30 & 3.04 & 1.32 & 1.57 & 2.00 & 1.28 \\
\hline$M A P 3 K 7 C L$ & 4 & 0.95 & 2.13 & 2.32 & 1.09 & 2.34 & 2.26 & 0.96 \\
\hline$N F K B 2$ & 11 & 1.32 & 1.40 & 1.69 & 1.20 & 1.18 & 1.85 & 1.56 \\
\hline RCANI & 6 & 1.13 & 2.28 & 5.38 & 2.36 & 1.34 & 2.02 & 1.51 \\
\hline$S E C 23 B$ & 3 & 1.36 & 1.32 & 1.07 & 0.81 & 3.27 & 1.24 & 0.38 \\
\hline SNAII & 5 & 1.51 & 1.08 & 1.27 & 1.17 & 1.22 & 1.17 & 0.96 \\
\hline TRIB3 & 5 & 1.10 & 3.79 & 3.79 & 1.00 & 2.34 & 2.61 & 1.12 \\
\hline WARS & 3 & 1.58 & 1.54 & 1.83 & 1.19 & 1.44 & 1.64 & 1.14 \\
\hline$G A D D 34$ & 14 & 0.27 & 1.43 & 2.37 & 1.65 & 3.05 & 2.37 & 0.78 \\
\hline ZNF432 & 3 & 1.01 & 1.08 & 1.09 & 1.01 & 1.12 & 1.44 & 1.29 \\
\hline$X B P 1 s$ & & 8.73 & 10.60 & 2.20 & 0.21 & 15.21 & 1.46 & 0.10 \\
\hline
\end{tabular}

limited effect on HSPA5 (BiP) expression during ER stress [57]. Importantly, we also observed that $E R N 1, B B C 3$, and regulator of calcineurin 1 ( $R C A N I$ ) were induced by both stressors and their levels were even higher after $X B P 1$ silencing. Notably, we recently identified $R C A N 1$ as an important prosurvival regulator of ER stress-induced cell fate decisions [21].

We also noted the induction of ER stress proapoptotic cyclin-dependent kinase inhibitor 1A (CDKN1A (p21)) and cytoplasmic linker $2(C L I P 2)$ expression upon XBP1 
silencing. Interestingly, CLIP2 has been associated as a key gene for diabetes mellitus development [64]. The PERK-dependent cyclin-dependent kinase 6 (CDK6 [65]) expression was significantly reduced only by $\mathrm{Tg}$ and its levels became even lower upon $X B P 1$ silencing during both Tm and Tg treatments. ANK2, ATF3 and GADD45A mRNAs were induced by both stressors and their levels were further elevated upon XBP1 silencing during $\mathrm{Tg}$ treatment. Notably, the UPR-induced proapoptotic GADD45A [21] has been proposed as an XBP1-dependent gene [57]. Furthermore, HSPA6 mRNA levels were significantly induced upon $X B P 1$ silencing in $\mathrm{Tm}$ - and $\mathrm{Tg}$ treated cells, but the expression of the HSPA6 gene was exceptionally low in HeLa cells, however, and therefore, this observation will require further verification.

We also observed that $X B P 1$ silencing resulted in lower expression of the transcription factor involved in ER stress-related regulation of cell cycle progression early growth response 1-EGRI [66] in both stress models. In addition, $X B P 1$ silencing induced the anti-apoptotic dualspecificity phosphatase 6-DUSP6 gene [67] expression in Tm-treated cells. Notably, DDIT3 (CHOP) and GADD34 levels were significantly induced in both ER stress models, and further increased upon $X B P 1$ silencing in Tg-treated cells whereas they were reduced in Tm-treated cells (Fig. 5A). Furthermore, we did not find any significant correlation between the potential number of XBP1-binding motifs and their connection to actual functional effects. Importantly, the functional analysis of all these verified XBP1-related genes indicated that they were almost exclusively connected to ER stress outcomes including all three UPR branches and ERAD, and the regulation of apoptotic processes (Fig. 5B).

Despite some discrepancies between the data obtained from the $X B P 1$ induction and silencing in different ER stress models, we were able to define a group of genes whose expression was XBP1 dependent, and their expression was significantly affected in at least two out of three independent experimental approaches (XBP1 induction; silencing $X B P 1 s$ during Tm treatment; or silencing XBP1s during $\mathrm{Tg}$ treatment) (Table 1). As shown in Fig. 5C, this resulted in a final selection of a group of 17 genes. In this gene set, the expression of six genes (HSPA5, CDK6, DNAJB9, EDEM1, $E G R 1$, and $S E C 23 B$ ) was positively correlated with the XBP1 levels.

Notably, we also identified three genes, $B B C 3, E R N 1$ and HSPA6, whose expression was negatively correlated with the $X B P 1$ expression in both ER stress models. Given that XBP1-mediated attenuation of ERN1 expression suggests a novel negative-feedback regulatory loop between XBP1 and IRE1, we also tested if XBP1-related reduction of ERN1 mRNA levels were reflected by IRE1 protein changes in Tmand $\mathrm{Tg}$-treated cells. In HeLa cells exposed to both Tm and
$\mathrm{Tg}$, the phosphorylated IRE1 protein levels were increased upon $X B P 1$ silencing as shown in Fig. 6.

Given that $B B C 3$-encoded PUMA protein was reported as an important apoptotic factor during UPR, we also tested if XBP1-related reduction of $B B C 3 \mathrm{mRNA}$ levels were reflected by PUMA protein changes. As shown in Fig. 7A, in HeLa cells exposed to Tm $(2.5 \mu \mathrm{g} / \mathrm{ml})$, PUMA protein levels were negatively correlated with $X B P 1 s$ expression and reduced after $8 \mathrm{~h}$ when the XBP1 expression is maximal. Furthermore, when XBP1 is reduced after $16 \mathrm{~h}$ of treatment, the PUMA levels rise. To support the idea of the negative correlation, we performed an experiment to test the idea of maintaining XBP1s levels by keeping transgenic XBP1s levels high at $16 \mathrm{~h}$ during Tm treatment to see the effect on PUMA expression (Fig. 7B, C). The results clearly show that higher XBP1s levels prevented PUMA accumulation during Tm ER stress at $16 \mathrm{~h}$, confirming XPB1s repression on PUMA expression.

To test XBP1's impact on prosurvival UPR activity, we subjected HeLa cells to Tm-induced ER stress for $16 \mathrm{~h}$ and measured caspase 3/7 activity. We directly compared Tminduced ER stress to Tm-induced stress in the presence of IRE1 inhibitor $(4 \mu 8 \mathrm{C})$ which would prevent IRE1 RIDD activity during XBP1s mRNA formation. We found that impairing IRE1 activity accelerates cell death in ER-stressed cells, whereas XBP1s expression correlated with a clear prosurvival effect (Fig. 7D). It has been previously reported that upon XBP1 deficiency, IRE1 switches to perform RIDD [68]. Nevertheless, given that the PUMA mRNA sequence does not contain the IREI-required consensus sequence (CUGCAG) [69], it seems unlikely that this transcript is degraded by RIDD. Furthermore, inhibiting this IRE1 activity can also prevent death receptor 5 (DR5) mRNA degradation and thus apoptosis engagement via caspase-8 [16]. Finally, since PUMA was reported to stimulate the intrinsic pathway of apoptosis [70,71], we performed an analogous experiment and siRNA silenced PUMA (Fig. 7E). Interestingly, we did not observe any significant changes in caspase 3/7 activity related to PUMA depletion (Fig. 7E). PUMA or $\mathrm{BH} 3$ protein (Bid) can separately activate $\mathrm{Bax}[72,73]$, and this could potentially lead to mitochondrial outer membrane permeability and apoptosis [74]. In the absence of PUMA, other BH3-only proteins (Bid and Bim) that are PERK dependent $[75,76]$ could still be efficiently activating caspase $3 / 7$.

To generalize the findings to other cell types, we followed consequences of $X B P 1$ silencing on both ERNI and $B B C 3$ mRNA levels in several other human cell lines exposed to ER stress that included Schwann Cells (SNF96.2), epidermal keratinocytes (HaCaT), umbilical vein endothelial cells (HUVEC) and bronchial epithelial cells (16HBE14o-). As shown in Supplemental Figure S3, $\mathrm{BBC} 3$ expression was significantly induced upon $\mathrm{XBP} 1$ 

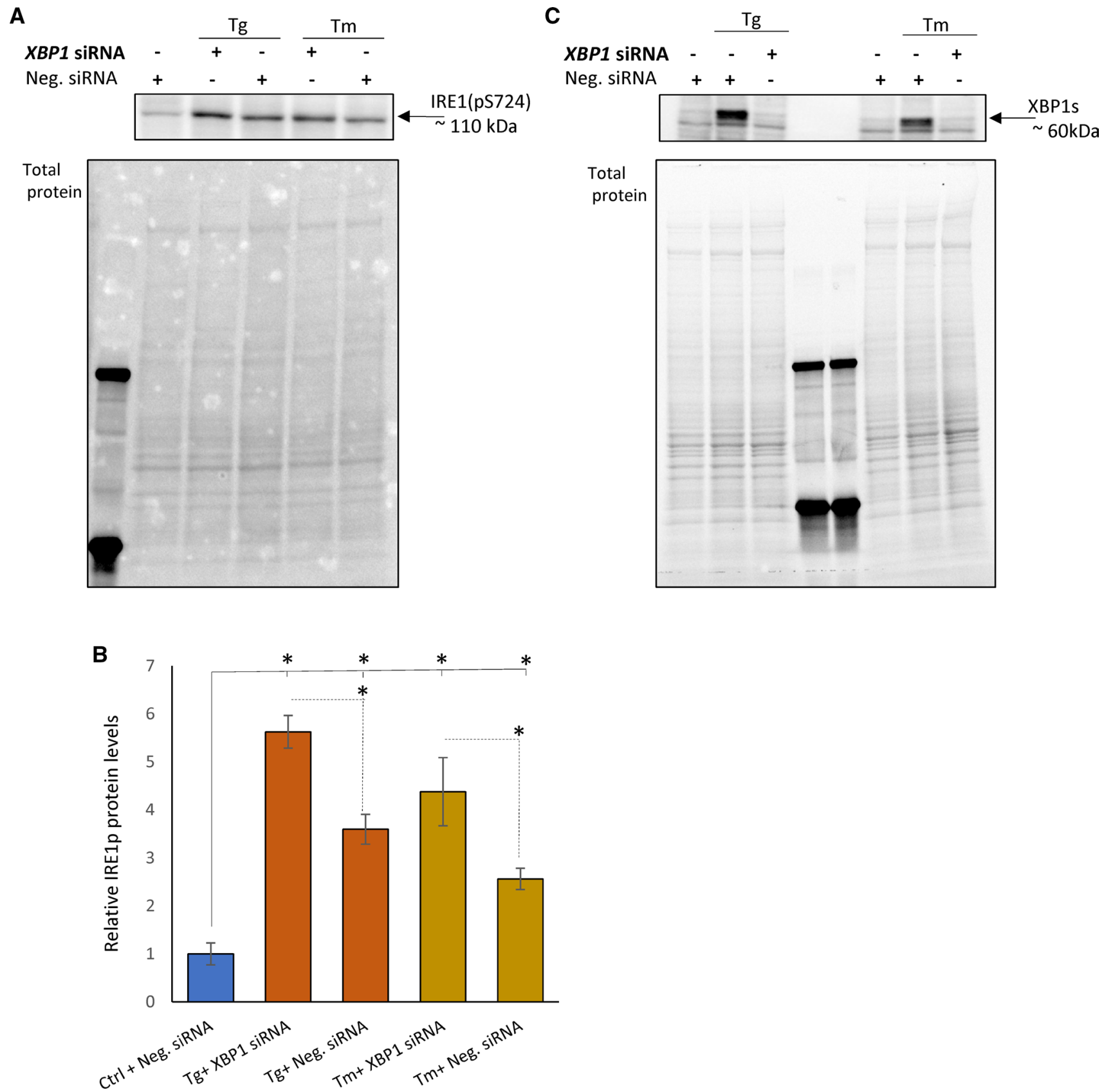

Fig. 6 The $X B P 1 s$ silencing is accompanied by reduced IRE1p protein levels in Tg- and Tm-treated HeLa cells. A Representative changes in IRE1p protein levels in HeLa cells treated with $\mathrm{Tg}(50 \mathrm{nM})$ and $\mathrm{Tm}(2.5 \mu \mathrm{g} / \mathrm{ml})$ and $\mathrm{Tg}$ for $6 \mathrm{~h}$ in the presence or absence of a specific siRNA against $X B P 1$ as evaluated by West-

silencing in all of these experimental models. Furthermore, ERN1 levels were modestly but significantly higher in the absence of XBP1s in all Tg-treated cell lines as well in HaCaTs and HUVECs treated with Tm (Supplemental Figure S3). These data support the general repressive role of XBP1 on ERN1 levels in a diverse group of human cell lines. ern blot and $\mathbf{B}$ normalized to total protein levels and related to the no-stress control. The experiments were repeated three times. Error bars represent standard deviations and $* P<0.05$ was considered significant. $\mathbf{C}$ The corresponding changes in XBP1 protein levels were evaluated by Western blot

In summary, we identified eight genes whose expression was ER stress model-dependent and/or not affected by XBP1 induction alone: DUSP6, DDIT3, GADD34, RCAN1, ICAM1, DNAJB2, CLIP2 and CDKNIA. This set contains mainly genes that can be attributed to the PERK pathway activity (DDIT3, GADD34) and cell survival (DDIT3, GADD34, RCAN1 and CDKN1A), suggesting that their 


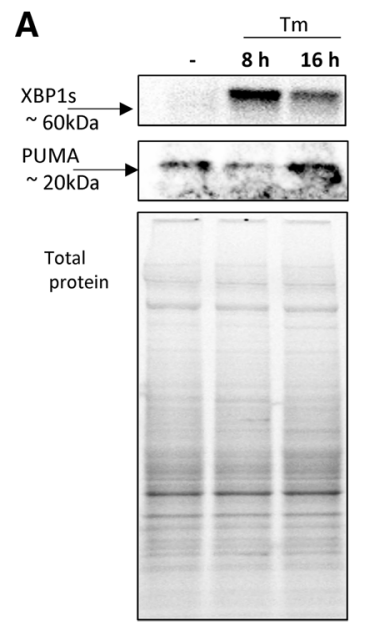

D

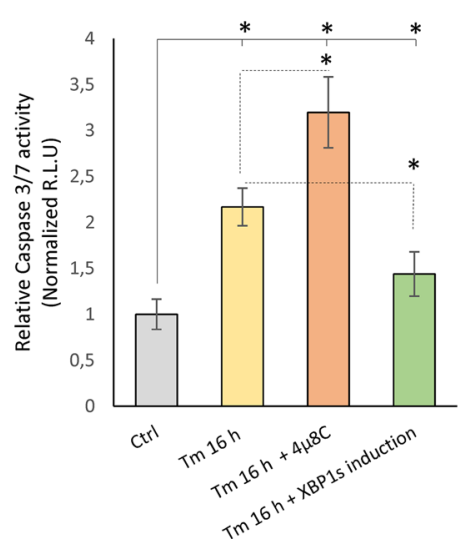

B

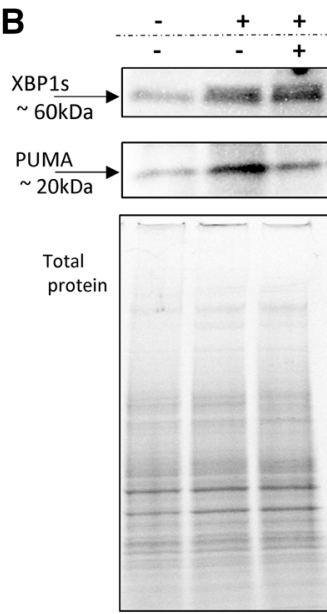

$\operatorname{Tm}(16 \mathrm{~h})$

$X B P 1 s$ Induction

\section{C}

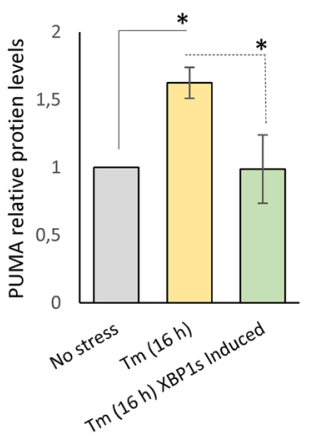

Fig. 7 The $24 \mathrm{~h}$ induction of $X B P 1 s$ is accompanied by reduced PUMA protein levels and lower Caspase $3 / 7$ activity in Tm-treated HeLa cells. A Representative changes in XBP1 and PUMA protein levels in HeLa cells treated with Tm $(2.5 \mu \mathrm{g} / \mathrm{ml})$ for 8 and $16 \mathrm{~h}$ as evaluated by Western blot. B The changes in XBP1 and PUMA protein levels in $X B P 1 s$-induced and -noninduced HeLa cells treated with $\mathrm{Tm}(2.5 \mu \mathrm{g} / \mathrm{ml}) 16 \mathrm{~h}$ were evaluated by Western blot $(\mathbf{C})$ normalized to total protein levels and related to the noninduced, no-stress control, and $* P<0.05$ was considered significant. $X B P 1 s$-induced $(24 \mathrm{~h})$ and -noninduced HeLa cells were treated with Tm $(2.5 \mu \mathrm{g} /$ $\mathrm{ml})$ for $16 \mathrm{~h}$ in the presence or absence of $4 \mu 8 \mathrm{C}(20 \mu \mathrm{M})$, a specific IRE1 activity inhibitor. D The caspase $3 / 7$ activity was monitored by

levels result from both XBP1 activity and other UPR pathways, including the PERK pathway.

\section{Discussion}

The IRE1-dependent pathway is the most ancient and conserved branch of UPR [25] and serves as the molecular timer and executor for ER stress-related cell death [77-79]. It is, therefore, not surprising that the role of its downstream transcription factor, XBP1, has been extensively studied [44, $49,57-59,80,81]$. The transcriptional targets of XBP1 are well identified and consist of ERAD components (EDEMI), luminescence and expressed in relative light units (RLU). Cells for each time point were seeded in triplicate, and the experiments were repeated three times. Error bars represent standard deviations and $* P<0.05$ was considered significant. The corresponding changes in XBP1 protein levels were evaluated by Western blot. E HeLa cells were treated with $\mathrm{Tm}(2.5 \mu \mathrm{g} / \mathrm{ml})$ for $16 \mathrm{~h}$ in the presence or absence of a specific siRNA against $B B C 3$ (PUMA). The caspase 3/7 activity was monitored by luminescence and expressed in RLU. Cells for each time point were seeded in triplicate, and the experiments were repeated three times. Error bars represent standard deviations, $* P<0.05$ was considered significant. The corresponding changes in PUMA protein levels were evaluated by Western blot

chaperones (HSPA5, DNAJB9, and DNAJC3), and vesicletrafficking components $(S E C 23 B)$ [57-59, 80]. Furthermore, genes involved in the inflammatory responses (including IL6) [59], as well as genes not related to UPR pathways including adipocyte and myogenic differentiation ( $C / E B P$ and $M I S T 1$ ) have been proposed as tissue-dependent XBP1 transcriptional targets [82]. Consequently, the XBP1 has been widely accepted as an adaptive component of UPR that is responsible for facilitating protein folding and ER expansion.

Despite these advances, determining the global network of XBP1 transcriptional activity and its consequences on cell fate decisions remains less clear. Part of the problem in 
defining XBP1's role involves analyzing its function in models that are often based on one type of ER stressor or are utilizing high levels of overexpression of XBP1. Furthermore, the studies often focus on a small subset of induced genes. In our approach, we exploited inducible cell lines capable of $X B P 1(s)$ and $X B P 1(u)$ lower expression levels and two models of pharmacological ER stress induction, glycosylation inhibition and disruption of ER calcium homeostasis. Using this system, we were able to demonstrate the induction of the main UPR mediators including HSPA5 (BIP), IRE1, $X B P 1 s$ and $C H O P$. Notably, the levels of XBP1s mRNA obtained during cell line induction were on the low end of those observed in our ER stress models.

To follow the XBP1-related changes in transcriptome, we performed next-generation sequencing profiling in $\mathrm{HeLa}$ cells with the induced expression of XBPIs or XBPIu and focused on changes in gene expression related mainly to prosurvival and apoptotic UPR signaling pathways. Notably $X B P 1 u$ expression did not result in any changes in which we could clearly assign to these activities. The unspliced XBP1 protein has been shown to be rapidly degraded and maintained at low levels and the XBPIu transgene transcript could not be processed to functional XBP1, and our results are in good agreement with previous reports [54].

Nevertheless, the $X B P 1 s$ transgene induction resulted in wide changes of expression profiles of the genes involved in the UPR including DNAJB9 and EDEM1, stress responses, and regulation of cellular biosynthetic and apoptotic responses (Fig. 4). The results confirmed XBP1's role as a crucial UPR mediator and potentially defined a large set of genes which resulted from XBP1 transcriptional activity. Importantly, following XBP1s induction, we did not observe some of the classical UPR activation genes since both $B I P$ and $C H O P$ mRNA levels remained relatively constant, and therefore, it is quite plausible that the observed transcriptomic changes often seen did not result specifically from XBP1 activity.

To further test this hypothesis, we selected a set of 58 genes (Supplemental Table 2) whose genomic locations were in the proximity of XBP1-binding motifs and DDIT3 and HSPA5 and validated them independently. The results revealed XBP1-related changes in 40 transcripts, most of which were related to the UPR stress responses and regulation of apoptosis (Fig. 5). The number of potential XBP1binding motifs in the promoter regions of genes did not correlate well with their transcript expression levels, suggesting that other requirements such as the relative position from the transcriptional start site or the presence of other potential binding motifs (such as ATF6 for example [57, 59]) may be necessary to achieve efficient transcription. However, the effects of the number of transcription factorbinding motifs on expression are only observed for some transcription factors [83]. Nevertheless, homotypic clusters of motifs for some transcription factors are known to potentiate the effects of these factors on expression for some genes [84]. Therefore, we also tested our gene set for a correlation between XBP1 motif clusters and fold changes, but no significant effects were observed. Finally, taking into account extreme complexity and dynamic course of UPR signaling, it is important to note that XBP1 cooperates with the other arms of UPR to modulate transcriptomic profiles, rather than being a master regulator of gene expression. Nevertheless, most of the preselected genes displayed expression patterns that positively correlated with the elevated expression levels of XBP1.

Despite our best efforts to find the optimal mild ER stress conditions, Tm and Tg still have different effects on the course of the UPR signaling pathways. For example, the Tm-treated cells were more prone to apoptosis (Fig. 1). We suggest that these differences between $\mathrm{Tm}$ and $\mathrm{Tg}$ could result in differences in the expression profiles of the cell fate decisions and the PERK-induced genes that include DDIT3, GADD34, ATF3 and RCAN1. In general, silencing XBP1s during Tg treatment resulted in higher expression of DDIT3, GADD34, ATF3 and RCAN1, whereas a complete lack of XBP1 during Tm treatment resulted in reduced expression of these genes. Since all these transcripts are closely related to the PERK branch of UPR, there exists the intriguing possibility of XBP1-mediated crosstalk between this pathway and the IRE1 branch that determines cell fate decisions [85, 86]. This hypothesis is also supported by the observation that inhibiting the PERK arm of the UPR has a different impact on XBP1s mRNA levels in cells treated with Tm when compared to cells treated with $\mathrm{Tg}$ (Supplemental Figure S4). All these genes are also potentially regulated by the other UPR-related transcription factors including CHOP and ATF6 (Supplemental Table S3). Hence, our results suggest that the gene expression modulations by XBP1 can also be influenced by other UPR pathways. This hypothesis, however, and the related mechanisms controlling this will obviously require further study.

Despite the differences between the data obtained from the XBP1 induction and silencing in different ER stress models, we were able to define a group of genes whose expression was clearly XBP1 dependent (Fig. 5C). The expression of HSPA5, CDK6, DNAJB9, EDEM1, EGR1, and SEC23B was clearly positively correlated with the XBP1 levels. In all these genes, their expression was not only induced along with $X B P 1 s$ induction, but it was also reduced when $X B P 1$ was silenced in both stress models. However, HSPA5, EGRI and $C D K 6$ only correlate positively in our ER stress-induced conditions and not in an XBPI overexpression model, suggesting that ATF6 may also be required for their expression induction [57, 59, 87].

Here, we have identified the 3 genes, BBC3 (PUMA), ERN1 (IRE1) and HSPA6 (BiP), whose expression was 
clearly negatively correlated with the XBP1, and their levels were reduced upon $X B P 1$ induction and induced upon $X B P 1$ silencing in both stress models. In the case of HSPA6, the expression levels in HeLa cells were extremely low, and therefore, may represent a cell-type-specific effect. The expression levels for the $B B C 3$ and $E R N 1$, however, were more robust and clearly indicated this reversal effect during siRNA silencing of XBP1s. Obviously, both $B B C 3$ (PUMA) and ERNI (IRE1) are crucial UPR regulators, and their XBP1-dependent repression reveals a novel regulatory mechanism in the UPR.

The ability of XBP1 to attenuate ERNI expression and thus reduce IRE1 activity identifies novel negative-feedback regulatory loop between XBP1 and IRE1. Although this observation and potential consequences of such a regulation requires further verification, it is clear that other UPR branches have negative effects on IRE1 activity that include PERK [79] and ATF6 [88]. Nevertheless, the implications of this during ER stress are that XBP1 controls its own levels and cell fate by limiting IRE1 activity.

Furthermore, numerous reports proposed that PUMA as an important and PERK-related contributor to UPR-related cell death [89-91], since it can inhibit all prosurvival Bcl-2 family members and activate the intrinsic pathway of apoptosis $[70,71]$. Hence, it is plausible that by preventing $B B C 3$ (PUMA) accumulation, XBP1 modulates the extent of intrinsic apoptotic signaling and thus contributes to the adaptive UPR response. Although our data clearly show that XBP1s induction leads to a reduction of PUMA protein levels, and at the same time reduces the extent of apoptotic UPR signaling (Fig. 6), evaluating the exact contribution of XBP1's role will require further study.

Taken together, our approach not only confirmed previously known XBP1 roles during the UPR [24], but also identified novel targets of this transcription factor that regulate the mechanisms of the UPR cell fate decisions. Having said that, our experimental approaches are limited by the complexity of UPR signaling pathways and all the other factors involved in this process, and therefore, further studies will be necessary to understand the complex relationships between XBP1 and all of its targets. One of the limitations here is that the time (at least $24 \mathrm{~h}$ ) required to obtain sufficient XBP1 expression prevents the model from reproducing the acute stress response since IRE1 is transiently activated and rapidly downregulated by the PERK arm of the stress response [78].

In summary, the studies presented here have identified that XBP1 can repress expression of two key players involved in UPR, IREI and PUMA, and further studies are obviously required to decipher the molecular mechanisms underlying this observation.

The results from three independent experiments are normalized to GAPDH and RPLPO mRNA levels and expressed as a fold change (FC) over the respective controls. For induction experiments during ER stress, normalization was performed against noninduced and non-ER stress exposed cells, whereas for silencing experiments, the noninduced negative control siRNA-transfected cells that were not exposed to ER stress were used as a control. Significant changes $(P$ value $P<0.05)$ are marked in grey. The Supplemental Table $2 \mathrm{AB}$ contains all the individual values.

Supplementary Information The online version contains supplementary material available at https://doi.org/10.1007/s00018-021-03952-1.

Acknowledgements We would like to thank Anna Janszak-Jasiecka and Marcin Serocki for their kind assistance.

Author contributions Conceived and designed the experiments: RB. Performed the experiments: MG, AS, and SB. Analyzed the data: RB, JFC, ACJK, DKC, PM, and MD. Contributed reagents/materials/ resources: RB. Wrote the paper: RB and JFC. All the authors read the final version of the manuscript.

Funding This research was funded by National Science Center "OPUS" Program under contract UMO-2020/37/B/NZ3/00861 to RB. J.F.C. was funded by an NIH P30 DK072482 and a Research Development Program Grant from the Cystic Fibrosis Foundation.

Data availability Deep sequencing data were deposited in Gene Expression Omnibus (GEO) at accession number: GSE160416.

\section{Declarations}

Conflict of interest The authors declare no conflict of interest. The funders had no role in the design of the study, in the collection, analyses, or interpretation of data or in the writing of the manuscript or in the decision to publish the results.

Open Access This article is licensed under a Creative Commons Attribution 4.0 International License, which permits use, sharing, adaptation, distribution and reproduction in any medium or format, as long as you give appropriate credit to the original author(s) and the source, provide a link to the Creative Commons licence, and indicate if changes were made. The images or other third party material in this article are included in the article's Creative Commons licence, unless indicated otherwise in a credit line to the material. If material is not included in the article's Creative Commons licence and your intended use is not permitted by statutory regulation or exceeds the permitted use, you will need to obtain permission directly from the copyright holder. To view a copy of this licence, visit http://creativecommons.org/licenses/by/4.0/.

\section{References}

1. Berridge MJ (2002) The endoplasmic reticulum: a multifunctional signaling organelle. Cell Calcium 32:235-249

2. Urra H, Dufey E, Lisbona F, Rojas-Rivera D, Hetz C (2013) When ER stress reaches a dead end. Biochem Biophys Acta 1833:3507-3517

3. Schroder M, Kaufman RJ (2005) ER stress and the unfolded protein response. Mutat Res 569:29-63 
4. Sano R, Reed JC (2013) ER stress-induced cell death mechanisms. Biochem Biophys Acta 1833:3460-3470

5. Yoshida H, Matsui T, Yamamoto A, Okada T, Mori K (2001) XBP1 mRNA is induced by ATF6 and spliced by IRE1 in response to ER stress to produce a highly active transcription factor. Cell 107:881-891

6. Back SH, Lee K, Vink E, Kaufman RJ (2006) Cytoplasmic IRE1alpha-mediated XBP1 mRNA splicing in the absence of nuclear processing and endoplasmic reticulum stress. J Biol Chem 281:18691-18706

7. Lee K, Tirasophon W, Shen X, Michalak M, Prywes R, Okada T, Yoshida H, Mori K, Kaufman RJ (2002) IRE1-mediated unconventional mRNA splicing and S2P-mediated ATF6 cleavage merge to regulate XBP1 in signaling the unfolded protein response. Genes Dev 16:452-466

8. Uemura A, Oku M, Mori K, Yoshida H (2009) Unconventional splicing of XBP1 mRNA occurs in the cytoplasm during the mammalian unfolded protein response. J Cell Sci 122:2877-2886

9. Schroder M, Kaufman RJ (2005) The mammalian unfolded protein response. Annu Rev Biochem 74:739-789

10. Karagoz GE, Acosta-Alvear D, Walter P (2019) The unfolded protein response: detecting and responding to fluctuations in the protein-folding capacity of the endoplasmic reticulum. Cold Spring Harb Perspect Biol. https://doi.org/10.7554/eLife.43036

11. Oyadomari S, Mori M (2004) Roles of CHOP/GADD153 in endoplasmic reticulum stress. Cell Death Differ 11:381-389

12. Urano F, Wang X, Bertolotti A, Zhang Y, Chung P, Harding HP, Ron D (2000) Coupling of stress in the ER to activation of JNK protein kinases by transmembrane protein kinase IRE1. Science 287:664-666

13. Hitomi J, Katayama T, Eguchi Y, Kudo T, Taniguchi M, Koyama Y, Manabe T, Yamagishi S, Bando Y, Imaizumi K, Tsujimoto Y, Tohyama M (2004) Involvement of caspase-4 in endoplasmic reticulum stress-induced apoptosis and Abeta-induced cell death. J Cell Biol 165:347-356

14. Li J, Lee B, Lee AS (2006) Endoplasmic reticulum stress-induced apoptosis: multiple pathways and activation of p53-up-regulated modulator of apoptosis (PUMA) and NOXA by p53. J Biol Chem 281:7260-7270

15. Lam M, Marsters SA, Ashkenazi A, Walter P (2020) Misfolded proteins bind and activate death receptor 5 to trigger apoptosis during unresolved endoplasmic reticulum stress. Elife. https://doi. org/10.7554/eLife.522919

16. Lu M, Lawrence DA, Marsters S, Acosta-Alvear D, Kimmig P, Mendez AS, Paton AW, Paton JC, Walter P, Ashkenazi A (2014) Opposing unfolded-protein-response signals converge on death receptor 5 to control apoptosis. Science 345:98-101

17. Wang S, Kaufman RJ (2012) The impact of the unfolded protein response on human disease. J Cell Biol 197:857-867

18. Hetz C (2012) The unfolded protein response: controlling cell fate decisions under ER stress and beyond. Nat Rev Mol Cell Biol 13:89-102

19. Hetz C, Chevet E, Oakes SA (2015) Proteostasis control by the unfolded protein response. Nat Cell Biol 17:829-838

20. Shore GC, Papa FR, Oakes SA (2011) Signaling cell death from the endoplasmic reticulum stress response. Curr Opin Cell Biol 23:143-149

21. Bartoszewski R, Gebert M, Janaszak-Jasiecka A, Cabaj A, Kroliczewski J, Bartoszewska S, Sobolewska A, Crossman DK, Ochocka R, Kamysz W, Kalinowski L, Dabrowski M, Collawn JF (2020) Genome-wide mRNA profiling identifies RCAN1 and GADD45A as regulators of the transitional switch from survival to apoptosis during ER stress. FEBS J 287:2923-2947

22. Rutkowski DT, Arnold SM, Miller CN, Wu J, Li J, Gunnison KM, Mori K, Sadighi Akha AA, Raden D, Kaufman RJ (2006)
Adaptation to ER stress is mediated by differential stabilities of pro-survival and pro-apoptotic mRNAs and proteins. Plos Biol 4:e374

23. Karam R, Lou CH, Kroeger H, Huang L, Lin JH, Wilkinson MF (2015) The unfolded protein response is shaped by the NMD pathway. Embo Rep 16:599-609

24. Acosta-Alvear D, Zhou Y, Blais A, Tsikitis M, Lents NH, Arias C, Lennon CJ, Kluger Y, Dynlacht BD (2007) XBP1 controls diverse cell type- and condition-specific transcriptional regulatory networks. Mol Cell 27:53-66

25. Zhang L, Zhang C, Wang A (2016) Divergence and conservation of the major UPR Branch IRE1-bZIP signaling pathway across eukaryotes. Sci Rep 6:27362

26. Chen H, Qi L (2010) SUMO modification regulates the transcriptional activity of XBP1. Biochem J 429:95-102

27. Lee J, Sun C, Zhou Y, Lee J, Gokalp D, Herrema H, Park SW, Davis RJ, Ozcan U (2011) p38 MAPK-mediated regulation of Xbp1s is crucial for glucose homeostasis. Nat Med 17:1251-1260

28. Wang FM, Chen YJ, Ouyang HJ (2011) Regulation of unfolded protein response modulator XBP1s by acetylation and deacetylation. Biochem J 433:245-252

29. Yanagitani K, Kimata Y, Kadokura H, Kohno K (2011) Translational pausing ensures membrane targeting and cytoplasmic splicing of XBP1u mRNA. Science 331:586-589

30. Majumder M, Huang C, Snider MD, Komar AA, Tanaka J, Kaufman RJ, Krokowski D, Hatzoglou M (2012) A novel feedback loop regulates the response to endoplasmic reticulum stress via the cooperation of cytoplasmic splicing and mRNA translation. Mol Cell Biol 32:992-1003

31. Bartoszewski R, Serocki M, Janaszak-Jasiecka A, Bartoszewska S, Kochan-Jamrozy K, Piotrowski A, Kroliczewski J, Collawn JF (2017) miR-200b downregulates Kruppel Like Factor 2 (KLF2) during acute hypoxia in human endothelial cells. Eur J Cell Biol 96:758-766

32. Barger CJ, Branick C, Chee L, Karpf AR (2019) Pan-cancer analyses reveal genomic features of FOXM1 overexpression in cancer. Cancers (Basel). 11:251

33. Malashicheva A, Kanzler B, Tolkunova E, Trono D, Tomilin A (2007) Lentivirus as a tool for lineage-specific gene manipulations (vol 45, pg 456, 2007). Genesis 45:793-793

34. Gomez-Martinez M, Schmitz D, Hergovich A (2013) Generation of stable human cell lines with Tetracycline-inducible (Tet-on) shRNA or cDNA expression. J Vis Exp. https://doi.org/10.3791/ 50171

35. Bartoszewska S, Kroliczewski J, Crossman DK, Pogorzelska A, Baginski M, Collawn JF, Bartoszewski R (2021) Triazoloacridone C-1305 impairs XBP1 splicing by acting as a potential IRE1alpha endoribonuclease inhibitor. Cell Mol Biol Lett 26:11

36. Gebert M, Bartoszewska S, Janaszak-Jasiecka A, Moszynska A, Cabaj A, Kroliczewski J, Madanecki P, Ochocka RJ, Crossman DK, Collawn JF, Bartoszewski R (2018) PIWI proteins contribute to apoptosis during the UPR in human airway epithelial cells. Sci Rep 8:16431

37. Lamkanfi M, Kanneganti TD (2010) Caspase-7: a protease involved in apoptosis and inflammation. Int J Biochem Cell Biol 42:21-24

38. Dobin A, Davis CA, Schlesinger F, Drenkow J, Zaleski C, Jha S, Batut P, Chaisson M, Gingeras TR (2013) STAR: ultrafast universal RNA-seq aligner. Bioinformatics 29:15-21

39. Trapnell C, Williams BA, Pertea G, Mortazavi A, Kwan G, van Baren MJ, Salzberg SL, Wold BJ, Pachter L (2010) Transcript assembly and quantification by RNA-Seq reveals unannotated transcripts and isoform switching during cell differentiation. Nat Biotechnol 28:511-515 
40. Kuleshov MV, Jones MR, Rouillard AD, Fernandez NF, Duan Q, Wang Z, Koplev S, Jenkins SL, Jagodnik KM, Lachmann A, McDermott MG, Monteiro CD, Gundersen GW, Ma' ayan A (2016) Enrichr: a comprehensive gene set enrichment analysis web server 2016 update. Nucleic Acids Res 44:W90-97

41. Bartoszewska S, Kamysz W, Jakiela B, Sanak M, Kroliczewski J, Bebok Z, Bartoszewski R, Collawn JF (2017) miR-200b downregulates CFTR during hypoxia in human lung epithelial cells. Cell Mol Biol Lett 22:23

42. Moszynska A, Collawn JF, Bartoszewski R (2020) IRE1 endoribonuclease activity modulates hypoxic HIF-1alpha signaling in human endothelial cells. Biomolecules. https://doi.org/10.3390/ biom 10060895

43. Livak KJ, Schmittgen TD (2001) Analysis of relative gene expression data using real-time quantitative PCR and the 2(-Delta Delta C(T)) Method. Methods (San Diego, Calif.) 25:402-408

44. Bartoszewska S, Cabaj A, Dabrowski M, Collawn JF, Bartoszewski R (2019) miR-34c-5p modulates X-box-binding protein 1 (XBP1) expression during the adaptive phase of the unfolded protein response. FASEB J 33:11541-11554

45. Consortium, E.P. (2012) An integrated encyclopedia of DNA elements in the human genome. Nature 489:57-74

46. Zerbino DR, Achuthan P, Akanni W, Amode MR, Barrell D, Bhai J, Billis K, Cummins C, Gall A, Giron CG, Gil L, Gordon L, Haggerty L, Haskell E, Hourlier T, Izuogu OG, Janacek SH, Juettemann T, To JK, Laird MR, Lavidas I, Liu Z, Loveland JE, Maurel T, McLaren W, Moore B, Mudge J, Murphy DN, Newman V, Nuhn M, Ogeh D, Ong CK, Parker A, Patricio M, Riat HS, Schuilenburg H, Sheppard D, Sparrow H, Taylor K, Thormann A, Vullo A, Walts B, Zadissa A, Frankish A, Hunt SE, Kostadima M, Langridge N, Martin FJ, Muffato M, Perry E, Ruffier M, Staines DM, Trevanion SJ, Aken BL, Cunningham F, Yates A, Flicek P (2018) Ensembl 2018. Nucleic Acids Res 46:D754-D761

47. Krystkowiak I, Lenart J, Debski K, Kuterba P, Petas M, Kaminska B, Dabrowski M (2013) Nencki Genomics Database-Ensembl funcgen enhanced with intersections, user data and genome-wide TFBS motifs. Database. https://doi.org/10.1093/database/bat069

48. Li J, Ni M, Lee B, Barron E, Hinton DR, Lee AS (2008) The unfolded protein response regulator GRP78/BiP is required for endoplasmic reticulum integrity and stress-induced autophagy in mammalian cells. Cell Death Differ 15:1460-1471

49. Bartoszewski R, Rab A, Fu L, Bartoszewska S, Collawn J, Bebok Z (2011) CFTR expression regulation by the unfolded protein response. Methods Enzymol 491:3-24

50. Shen J, Chen X, Hendershot L, Prywes R (2002) ER stress regulation of ATF6 localization by dissociation of BiP/GRP78 binding and unmasking of Golgi localization signals. Dev Cell 3:99-111

51. Iurlaro R, Munoz-Pinedo C (2016) Cell death induced by endoplasmic reticulum stress. FEBS J 283:2640-2652

52. Cross BC, Bond PJ, Sadowski PG, Jha BK, Zak J, Goodman JM, Silverman RH, Neubert TA, Baxendale IR, Ron D, Harding HP (2012) The molecular basis for selective inhibition of unconventional mRNA splicing by an IRE1-binding small molecule. Proc Natl Acad Sci USA 109:E869-878

53. Grimson A, Farh KK, Johnston WK, Garrett-Engele P, Lim LP, Bartel DP (2007) MicroRNA targeting specificity in mammals: determinants beyond seed pairing. Mol Cell 27:91-105

54. Tirosh B, Iwakoshi NN, Glimcher LH, Ploegh HL (2006) Rapid turnover of unspliced Xbp-1 as a factor that modulates the unfolded protein response. J Biol Chem 281:5852-5860

55. Yoshida H, Oku M, Suzuki M, Mori K (2006) pXBP1(U) encoded in XBP1 pre-mRNA negatively regulates unfolded protein response activator $\mathrm{pXBP}(\mathrm{S})$ in mammalian ER stress response. J Cell Biol 172:565-575
56. Heberle H, Meirelles GV, da Silva FR, Telles GP, Minghim R (2015) InteractiVenn: a web-based tool for the analysis of sets through Venn diagrams. BMC Bioinform 16:169

57. Lee AH, Iwakoshi NN, Glimcher LH (2003) XBP-1 regulates a subset of endoplasmic reticulum resident chaperone genes in the unfolded protein response. Mol Cell Biol 23:7448-7459

58. Misiewicz M, Dery MA, Foveau B, Jodoin J, Ruths D, LeBlanc AC (2013) Identification of a novel endoplasmic reticulum stress response element regulated by XBP1. J Biol Chem 288:20378-20391

59. Shaffer AL, Shapiro-Shelef M, Iwakoshi NN, Lee AH, Qian SB, Zhao H, Yu X, Yang L, Tan BK, Rosenwald A, Hurt EM, Petroulakis E, Sonenberg N, Yewdell JW, Calame K, Glimcher LH, Staudt LM (2004) XBP1, downstream of Blimp-1, expands the secretory apparatus and other organelles, and increases protein synthesis in plasma cell differentiation. Immunity 21:81-93

60. Gaudette BT, Jones DD, Bortnick A, Argon Y, Allman D (2020) mTORC1 coordinates an immediate unfolded protein responserelated transcriptome in activated $\mathrm{B}$ cells preceding antibody secretion. Nat Commun 11:723

61. Brush MH, Weiser DC, Shenolikar S (2003) Growth arrest and DNA damage-inducible protein GADD34 targets protein phosphatase 1 alpha to the endoplasmic reticulum and promotes dephosphorylation of the alpha subunit of eukaryotic translation initiation factor 2. Mol Cell Biol 23:1292-1303

62. Gupta S, Giricz Z, Natoni A, Donnelly N, Deegan S, Szegezdi E, Samali A (2012) NOXA contributes to the sensitivity of PERKdeficient cells to ER stress. Febs Lett 586:4023-4030

63. Fang P, Xiang L, Huang S, Jin L, Zhou G, Zhuge L, Li J, Fan H, Zhou L, Pan C, Zheng Y (2018) IRE1alpha-XBP1 signaling pathway regulates IL-6 expression and promotes progression of hepatocellular carcinoma. Oncol Lett 16:4729-4736

64. Liu GM, Zeng HD, Zhang CY, Xu JW (2019) Key genes associated with diabetes mellitus and hepatocellular carcinoma. Pathol Res Pract 215:152510

65. Brewer JW, Diehl JA (2000) PERK mediates cell-cycle exit during the mammalian unfolded protein response. Proc Natl Acad Sci USA 97:12625-12630

66. Shan J, Dudenhausen E, Kilberg MS (2019) Induction of early growth response gene 1 (EGR1) by endoplasmic reticulum stress is mediated by the extracellular regulated kinase (ERK) arm of the MAPK pathways. Biochim Biophys Acta Mol Cell Res 1866:371-381

67. Piya S, Kim JY, Bae J, Seol DW, Moon AR, Kim TH (2012) DUSP6 is a novel transcriptional target of p53 and regulates p53-mediated apoptosis by modulating expression levels of Bcl-2 family proteins. Febs Lett 586:4233-4240

68. Tang C-HA, Chang S, Paton AW, Paton JC, Gabrilovich DI, Ploegh HL, Del Valle JR, Hu C-CA (2018) Phosphorylation of IRE1 at S729 regulates RIDD in B cells and antibody production after immunization. J Cell Biol 217:1739-1755

69. Oikawa D, Tokuda M, Hosoda A, Iwawaki T (2010) Identification of a consensus element recognized and cleaved by IRE1 alpha. Nucleic Acids Res 38:6265-6273

70. Willis SN, Fletcher JI, Kaufmann T, van Delft MF, Chen L, Czabotar PE, Ierino H, Lee EF, Fairlie WD, Bouillet P, Strasser A, Kluck RM, Adams JM, Huang DC (2007) Apoptosis initiated when $\mathrm{BH} 3$ ligands engage multiple $\mathrm{Bcl}-2$ homologs, not Bax or Bak. Science 315:856-859

71. Gurzov EN, Germano CM, Cunha DA, Ortis F, Vanderwinden JM, Marchetti P, Zhang L, Eizirik DL (2010) p53 up-regulated modulator of apoptosis (PUMA) activation contributes to pancreatic beta-cell apoptosis induced by proinflammatory cytokines and endoplasmic reticulum stress. J Biol Chem 285:19910-19920

72. Jabbour AM, Heraud JE, Daunt CP, Kaufmann T, Sandow J, O'Reilly LA, Callus BA, Lopez A, Strasser A, Vaux DL, Ekert 
PG (2009) Puma indirectly activates Bax to cause apoptosis in the absence of Bid or Bim. Cell Death Differ 16:555-563

73. Garrison SP, Phillips DC, Jeffers JR, Chipuk JE, Parsons MJ, Rehg JE, Opferman JT, Green DR, Zambetti GP (2012) Genetically defining the mechanism of Puma- and Bim-induced apoptosis. Cell Death Differ 19:642-649

74. Pihán P, Carreras-Sureda A, Hetz C (2017) BCL-2 family: integrating stress responses at the ER to control cell demise. Cell Death Differ 24:1478-1487

75. Verfaillie T, Rubio N, Garg AD, Bultynck G, Rizzuto R, Decuypere JP, Piette J, Linehan C, Gupta S, Samali A, Agostinis P (2012) PERK is required at the ER-mitochondrial contact sites to convey apoptosis after ROS-based ER stress. Cell Death Differ 19:1880-1891

76. Giam M, Huang DCS, Bouillet P (2008) BH3-only proteins and their roles in programmed cell death. Oncogene 27:S128-S136

77. Chen Y, Brandizzi F (2013) IRE1: ER stress sensor and cell fate executor. Trends Cell Biol 23:547-555

78. Shemorry A, Harnoss JM, Guttman O, Marsters SA, Komuves LG, Lawrence DA, Ashkenazi A (2019) Caspase-mediated cleavage of IRE1 controls apoptotic cell commitment during endoplasmic reticulum stress. Elife 8:47084

79. Chang TK, Lawrence DA, Lu M, Tan J, Harnoss JM, Marsters SA, Liu P, Sandoval W, Martin SE, Ashkenazi A (2018) Coordination between two branches of the unfolded protein response determines apoptotic cell fate. Mol Cell 71:629-636

80. Byrd AE, Brewer JW (2012) Intricately regulated: a cellular toolbox for fine-tuning XBP1 expression and activity. Cells 1:738-753

81. Bartoszewski R, Rab A, Twitty G, Stevenson L, Fortenberry J, Piotrowski A, Dumanski JP, Bebok Z (2008) The mechanism of cystic fibrosis transmembrane conductance regulator transcriptional repression during the unfolded protein response. J Biol Chem 283:12154-12165

82. He Y, Sun S, Sha H, Liu Z, Yang L, Xue Z, Chen H, Qi L (2010) Emerging roles for XBP1, a sUPeR transcription factor. Gene Expr 15:13-25

83. Weingarten-Gabbay S, Nir R, Lubliner S, Sharon E, Kalma Y, Weinberger A, Segal E (2019) Systematic interrogation of human promoters. Genome Res 29:171-183
84. Lavallee JF, Gray TA, Dumville J, Russell W, Cullum N (2017) The effects of care bundles on patient outcomes: a systematic review and meta-analysis. Implement Sci 12:142

85. Gonen N, Sabath N, Burge CB, Shalgi R (2019) Widespread PERK-dependent repression of ER targets in response to ER stress. Sci Rep 9:4330

86. Tsuru A, Imai Y, Saito M, Kohno K (2016) Novel mechanism of enhancing IRE1 $\alpha$-XBP1 signalling via the PERK-ATF4 pathway. Sci Rep 6:24217

87. Yamamoto K, Sato T, Matsui T, Sato M, Okada T, Yoshida H, Harada A, Mori K (2007) Transcriptional induction of mammalian ER quality control proteins is mediated by single or combined action of ATF6alpha and XBP1. Dev Cell 13:365-376

88. Walter F, O'Brien A, Concannon CG, Düssmann H, Prehn JHM (2018) ER stress signaling has an activating transcription factor $6 \alpha$ (ATF6)-dependent “off-switch." J Biol Chem 293:18270-18284

89. Wali JA, Rondas D, McKenzie MD, Zhao Y, Elkerbout L, Fynch S, Gurzov EN, Akira S, Mathieu C, Kay TWH, Overbergh L, Strasser A, Thomas HE (2014) The proapoptotic BH3-only proteins Bim and Puma are downstream of endoplasmic reticulum and mitochondrial oxidative stress in pancreatic islets in response to glucotoxicity. Cell Death Dis 5:e1124-e1124

90. Szegezdi E, Logue SE, Gorman AM, Samali A (2006) Mediators of endoplasmic reticulum stress-induced apoptosis. EMBO Rep 7:880-885

91. Pagliarini V, Giglio P, Bernardoni P, De Zio D, Fimia GM, Piacentini M, Corazzari M (2015) Downregulation of E2F1 during ER stress is required to induce apoptosis. J Cell Sci 128:1166-1179

Publisher's Note Springer Nature remains neutral with regard to jurisdictional claims in published maps and institutional affiliations. 